\title{
The oestrogen metabolite 2-methoxy- oestradiol alone or in combination with tumour necrosis factor-related apoptosis-inducing ligand mediates apoptosis in cancerous but not healthy cells of the human endometrium
}

\author{
Sumie Kato ${ }^{1}$, Anil Sadarangani ${ }^{2}$, Soledad Lange ${ }^{2}$, Manuel Villalón $^{2}$, \\ Jorge Brañes ${ }^{1}$, Jan J Brosens ${ }^{3}$, Gareth I Owen ${ }^{2}$ and Mauricio Cuello ${ }^{1}$ \\ Departments of ${ }^{1}$ Obstetrics and Gynaecology, Faculty of Medicine and \\ ${ }^{2}$ Physiology, Faculty of Biological Sciences, Pontificia Universidad Católica de Chile, Alameda 340, Santiago, Casilla 114-D, Chile \\ ${ }^{3}$ Institute of Reproductive and Developmental Biology, Imperial College London, Hammersmith Hospital, London W12 0NN, UK \\ (Requests for offprints should be addressed to M Cuello; Email: macuello@med.puc.cl) \\ $\mathrm{S}$ Kato and $\mathrm{A}$ Sadarangani contributed equally to this work
}

\begin{abstract}
Cancers of the reproductive tract account for $12 \%$ of all malignancies in women. As previous studies have shown that oestrogen metabolites can cause apoptosis, we characterised the effect of oestrogen and oestrogen metabolites on non-cancerous and cancerous human endometrial cells. Herein, we demonstrate that 2-methoxyoestradiol (2ME), but not 17 $\beta$-oestradiol, induces apoptosis in cancer cell lines and primary cultured tumours of endometrial origin. In contrast, $2 \mathrm{ME}$ had no effect on cell viability of corresponding normal tissue. This ability of $2 \mathrm{ME}$ to induce apoptosis does not require oestrogen receptor activation, but is associated with increased entry into the G2/M phases of the cell cycle and the activation of both the intrinsic and the extrinsic apoptotic pathways. The selective behaviour of $2 \mathrm{ME}$ on cancerous as opposed to normal tissue may be due to a reduction in $17 \beta$-hydroxysteroid dehydrogenase type II levels in cancer cells and to a differential down-regulation of superoxide dismutase. Furthermore, we demonstrate that pre-treatment with $2 \mathrm{ME}$ enhances the sensitivity of reproductive tract cancer cells to the apoptotic drug tumour necrosis factor-related apoptosis-inducing ligand (TRAIL), without the loss in cell viability to normal cells incurred by currently chemotherapeutic drugs. In conclusion, $2 \mathrm{ME}$, alone or in combination with TRAIL, may be an effective treatment for cancers of uterine origin with minimal toxicity to corresponding healthy female reproductive tissue.
\end{abstract}

Endocrine-Related Cancer (2007) 14 351-368

\section{Introduction}

Cancer of the reproductive tract encompasses malignancies of the uterine cervix, uterine corpus, ovary, vulva, fallopian tube, vagina and other related genital tissue. According to recent estimates by the American Cancer Society, cancer of the reproductive tract will account for $12 \%$ of all female cancers (79 480 of 662870 estimated cases) and $\sim 15 \%$ of female cancerrelated mortalities (28 910 of 275000 estimated cases). Endometrial cancer is the most common gynaecologic malignancy and the fourth most common cancer in women (Amant et al. 2005, Carter \& Pather 2006). Approximately $75 \%$ of women present with diseases clinically confined to the uterus (stage 1 ), for which the overall 5-year survival is $75 \%$ (2). The prognosis for patients with more advanced or recurrent endometrial disease is poor, with a median survival of $<1$ year (Amant et al. 2005). Chemotherapy is the mainstay of the treatment for patients with advanced or recurrent disease. Due to the well-documented secondary effects 
of chemotherapy, there is a need to find new effective treatments for advanced endometrial cancers and other malignancies of the reproductive tract which confer minimal toxicity to normal healthy tissues.

One such candidate compound is the oestrogen metabolite 2-methoxyoestradiol (2ME), which is now in clinical trials for the treatment of various cancers (Mooberry 2003).2ME is produced by sequential hepatic hydroxylation and methylation from the parent compounds and is present in human blood and the urine (Watanabe et al. 1991, Suchar et al. 1995, Zhu \& Conney 1998). Oestradiol or oestrone can be hydroxylated at various positions by nicotinamide adenine dinucleotide phosphate (NADPH)-dependent cytochrome p450 enzymes CYP1A2 and CYP3A present in the liver and extrahepatic target cells (Franks et al. 1982, Watanabe et al. 1991). The chemically reactive catechol oestrogens (2- or 4-hydroxyoestradiol $(2 \mathrm{OH}$ or $4 \mathrm{OH})$ and 2- or 4-hydroxyoestrone $(2 \mathrm{OH}$ or $4 \mathrm{OH}))$ can be metabolically $O$-methylated to monomethylethers by catechol- $O$-methyltransferase (COMT), an enzyme present in large amounts in many organs and cells such as liver, kidney, placenta, uterus and mammary gland (Kopin 1994, Williams et al. 2002, Yue et al. 2003). The metabolite $2 \mathrm{ME}$ can bind to oestrogen receptors (ERs), albeit at a 500- and 3200-fold lower affinity than that of oestradiol for $E R \alpha$ and $E R \beta$ respectively. Along with the capability of utilising ER signalling pathways, several publications have highlighted that the anti-proliferative activities of $2 \mathrm{ME}$ can occur independently of ER signalling and are not altered by either oestrogen antagonists or agonists (Merriam et al. 1980, van Aswegen et al. 1989). 2ME has been shown to be a potent inhibitor of angiogenesis and suppresses tumour growth. It appears to target only active proliferating cells and not cytotoxic to quiescent cells (LaVallee et al. 2002). The exact action of $2 \mathrm{ME}$ is currently unknown; however, various mechanisms have been implicated. There is accordance in the literature that $2 \mathrm{ME}$ inhibits tumour proliferation, in vitro and in vivo, by inducing cell cycle arrest and apoptosis and by inhibiting angiogenesis. A dose-dependent G2/M arrest was found in a wide range of cancer cells and this effect is thought to be due to its toxicity to microtubules (Sidor et al. 2005) and inhibition of regulators of cell cycle progression (Qadan et al. 2001). Apoptosis is the programmed cell death that is essential for the development and tissue homeostasis of healthy cells. An apoptotic effect of $2 \mathrm{ME}$ has been shown both in vitro and in vivo (Basu et al. 2006, Gui \& Zheng 2006, Ray et al. 2006) and this mechanism involves both the intrinsic (up-regulation of p53, accumulation of reactive oxygen species (ROS), Bcl-2 phosphorylarion and inactivation) and extrinsic (up-regulation of DR5) apoptotic pathways (Bu et al. 2002, LaVallee et al. 2003, Zhou et al. 2004, Joubert et al. 2005, Thews et al. 2005).

Reports indicate that certain breast cancer cell lines are insensitive to 2ME. Mechanistically, this insensitivity is largely attributable to the presence of high levels of a steroid-selective metabolising enzyme, the type II $17 \beta$-hydroxysteroid dehydrogenase (17 $\beta$-HSD), which rapidly converts $2 \mathrm{ME}$ to the inactive 2-methoxyoestrone (Liu et al. 2005).

There is evidence that $2 \mathrm{ME}$ can overcome resistance to chemotherapy in several drug-resistant cancer cells, and its also been shown that $2 \mathrm{ME}$ has no anti-tumour effects on human endometrial carcinoma in in vivo models (Chauhan et al. 2002, Li et al. 2007). However, in these and other models, $2 \mathrm{ME}$ has been added orally or subcutaneously and has thus been subject to problems of metabolism in the liver. Due to the side effects of the current combined chemotherapy treatments, the combination of locally administered $2 \mathrm{ME}$ with other apoptotic drugs with minimal toxicity to healthy tissues would be an attractive alternative therapeutic strategy for the treatment of cancers of the female reproductive tract. One such drug is tumour necrosis factor-related apoptosis-inducing ligand (TRAIL), which we have previously shown to induce apoptosis in cancer cells but not in healthy cells of cervical, endometrial, fallopian tube or ovarian origin (Sadarangani et al. 2007). TRAIL acts by binding to the death receptors TRAIL-R1 (also called DR4) and TRAIL-R2 (also called DR5), thereby inducing caspase-mediated apoptosis.

In this study, we characterised the anti-proliferative and pro-apoptotic effects of $2 \mathrm{ME}$ in endometrial and cervical cancer cell lines, primary cultured cancer cells and corresponding non-malignant cells from the female reproductive tract. In addition, we demonstrate that $2 \mathrm{ME}$ enhances the apoptotic response to TRAIL.

\section{Materials and methods}

Primary tissue of human female reproductive tract was obtained with patient consent from the Gynaecology Department of the Hospital of the Pontificia Universidad Católica de Chile, in Santiago, Chile. Ethical approval for the study was obtained from both the ethical committees of the Faculty of Medicine and the Faculty of Biological Sciences at the Pontificia Universidad Católica de Chile and the South Eastern Health Service of Santiago, Chile.

\section{Cell culture}

Primary culture of normal and cancerous human endometrial epithelium, endometrial stroma, cervical, 
ovarian and fallopian tube were derived from tissue from pre-menopausal or postmenopausal women undergoing either hysterectomy alone or hysterectomy with bilateral salpingo-oophorectomy and from benign or malignant tumours as published previously (Sadarangani et al. 2007). The endometrial cancer cell lines Ishikawa (Nishida et al. 1985), HEC1A (Kuramoto 1972), the cervical cancer cell line HeLa (Eagle 1955), the breast cancer cell lines ZR-75 (Engel et al. 1978) and MDA-MB-231 (Cailleau et al. 1978) cells were maintained in Dulbecco's modified Eagle medium (DMEM)/F12 media supplemented with $10 \%$ foetal bovine serum (Invitrogen). For protein and RNA experiments, cells were plated at $50 \%$ confluence in $10 \mathrm{~cm}^{2}$ Petri dishes (Falcon, Becton-Dickinson, NJ, USA). The medium was changed to charcoal-treated medium containing 5\% serum for $24 \mathrm{~h}$ before the addition of $2 \mathrm{ME}$ or TRAIL.

\section{Reagents}

$17 \beta$-oestradiol $\left(\mathrm{E}_{2}\right)$ and $2 \mathrm{ME}$ were purchased from Sigma-Aldrich. All other oestrogen metabolites were purchased from Steraloids Inc. (Rhode Island, USA). glutathione-S-transferase (GST)-TRAIL fusion protein was produced as described previously (Cuello et al. 2001) and stored in aliquots at $-20{ }^{\circ} \mathrm{C}$. An equal volume of vehicle (DMEM/F12 medium or ethanol) was added as a control in each experiment. The tetrapeptide caspase inhibitor ZVAD-fmk(Z-Val-Ala-Asp $\left(\mathrm{OCH}_{3}\right)$ fmk), caspase inhibitors 2, 8 and 9 (Enzyme Systems Products, Livermore, CA, USA) were resuspended in DMSO (Sigma-Aldrich Co.) and added to the cells at a final concentration of $50 \mu \mathrm{M}, 30 \mathrm{~min}$ before TRAIL. $\mathrm{N}$-acetylcysteine (NAC) and ICI 182780 (ICI) were purchased from Sigma-Aldrich.

The chemotherapeutics drugs (doxorubicin (DOX), paclitaxel (PTX) and cisplatin (CIS)) were kindly given by the Cancer Center of the Pontificia Universidad Católica de Chile, and used at a final concentration of $5 \mu \mathrm{M}$.

\section{Measurement of cell viability and apoptosis}

The MTS assay was used to assess oestrogen, oestrogen metabolite and TRAIL-mediated cytotoxicity. Primary cultured cells or cancer cell lines were plated at $1-5 \times 10^{4}$ cells/well in 96-well microtiter plates and allowed to adhere to the plates $24 \mathrm{~h}$ in DMEM/F12 with $10 \%$ FBS. Cells were incubated in 5\% charcoal-stripped FBS containing DMEM/F12 medium for $24 \mathrm{~h}$ before addition of oestrogen metabolites, at concentrations stated in figure legends, for $48 \mathrm{~h}$. GST-TRAIL fusion protein was added under the same conditions and incubated for $18 \mathrm{~h}$. In experiments where cells were co-treated with $2 \mathrm{ME}$ and GST-TRAIL, the procedure was identical for that of the above-mentioned oestrogen metabolites, with GST-TRAIL being added to the medium during the last 18 -h treatment period. Cell viability was assessed by the MTS dye reduction assay (Cell Titer 96 AQ $_{\text {ueous }}$ One Solution Cell Proliferation Assay, Promega) at $490 \mathrm{~nm}$ (Keane et al. 1996). All MTS data points were performed five times in each assay and each experiment was carried out a minimum of three times. Results of representative experiments are given as the mean \pm s.D. and of multiple experiments as the mean \pm s.E.M.

\section{DNA fragmentation assay}

Cells $\left(2 \times 10^{6}\right)$ were washed in cold PBS and harvested in cold lysis buffer containing $10 \mathrm{mM}$ Tris- $\mathrm{HCl}, \mathrm{pH} 8.0$, $150 \mathrm{mM} \mathrm{NaCl}, 2 \mathrm{mM} \mathrm{MgCl} 2,1 \mathrm{mM}$ dithiothreitol (DTT) and $0.5 \% \mathrm{NP}-40$ on ice for $40 \mathrm{~min}$. Lysates were centrifuged at $13000 \mathrm{~g}$ and the pellets resuspended in cold buffer containing $10 \mathrm{mM}$ Tris- $\mathrm{HCl}, \mathrm{pH}$ $8.0,350 \mathrm{mM} \mathrm{NaCl}, 1 \mathrm{mM} \mathrm{MgCl}_{2}$ and $1 \mathrm{mM}$ DTT before incubation on ice for $20 \mathrm{~min}$. Lysates were then extracted once with phenol/chloroform and the DNA precipitated with $10 \mathrm{mM} \mathrm{MgCl}$ and 2.5 volumes of $100 \%$ ethanol overnight at $-20{ }^{\circ} \mathrm{C}$. DNA was collected by centrifugation at $14000 \mathrm{~g}$ for $20 \mathrm{~min}$, resuspended in TE buffer (10 mM Tris-HCl, pH 8.0, 1 mM EDTA) plus $0.1 \mathrm{mg} / \mathrm{ml}$ RNase A and incubated at $37^{\circ} \mathrm{C}$ for $1 \mathrm{~h}$. Proteinase $\mathrm{K}(1 \mathrm{mg} / \mathrm{ml})$ was added and the mixture was further incubated at $37^{\circ} \mathrm{C}$ for $1 \mathrm{~h}$. Fragmented DNA was separated by electrophoresis in a $1.5 \%$ agarose gel and visualised with ethidium bromide $(0.5 \mu \mathrm{g} / \mathrm{ml})$.

\section{Measurement of caspase-3, -8 and -9 activities}

Cultured cells were harvested and washed once in cold PBS. After a brief centrifugation $(3000 \mathrm{~g}, 5 \mathrm{~min})$ cells were incubated in lysis buffer containing $20 \mathrm{mM}$ Hepes (pH 7.4), $100 \mathrm{mM} \mathrm{NaCl}, 0.5 \%$ (v/v) NP-40 and $10 \mathrm{mM}$ DTT on ice for $30 \mathrm{~min}$. Following centrifugation at $13000 \mathrm{~g}$ for $10 \mathrm{~min}$ at $4{ }^{\circ} \mathrm{C}$, supernatants were collected, transferred to a 96 well plate and corresponding substrate to caspase-3, -8 and -9 (CalbiochemNovabiochem Corp., San Diego, CA, USA) added. The samples were incubated for $24 \mathrm{~h}$ at room temperature. Optical density at $405 \mathrm{~nm}$ was measured using an ELISA plate reader (EL310 Boots-Celtech). Caspase activity was expressed as percentage with respect to control, which was set at $100 \%$. Statistical analysis was performed by Mann-Whitney analysis with significance set at $P<0.05$. Bars represent \pm s.D. of the mean. 


\section{Western blotting}

Cells were harvested in cold PBS and the pellet resuspended in lysis buffer (10 mM Tris- $\mathrm{HCl} \mathrm{pH} 7.4$, $150 \mathrm{mM} \mathrm{NaCl}, 0.5 \%$ Triton $\mathrm{X}-100)$ for $20 \mathrm{~min}$ in ice. After this incubation, the lysate was sonicated and centrifuged at $14000 \mathrm{~g}$ for $20 \mathrm{~min}$ at $4{ }^{\circ} \mathrm{C}$ to separate membrane (pellet) and cytosolic (supernatant) fractions as previously described (Basak et al. 2005). Protein concentration was determined by Bradford assay. $100 \mu \mathrm{g}$ of crude membrane extract was loaded in each lane, separated by $10 \%$ polyacrylamide gel electrophoresis in the presence of sodium dodecylsulphate, transferred to nitrocellulose membranes and incubated overnight with primary antibodies (1:1000). Bcl-2 (DAKO, Carpinteria, CA, USA), cytochrome C (BD Biosciences, San Jose, CA, USA), phospho-Bcl-2 PARP, Bad, AIF, Bcl-xL, caspase- 9 and $\beta$-actin (Santa Cruz, CA, USA), Survivin (R\&D System, Minneapolis, MN, USA), Flip, caspase-3, -8 and Bid (Calbiochem, San Diego, CA, USA), SMAC/Diablo (BD Transduction Laboratories, CA, USA). Secondary antibody, goat anti-mouse/rabbit IgG secondary antibody coupled to hydrogen peroxidase (1:5000, The reaction was developed with chemiluminescence using ECL western blot analysis system (NEN, Western lightning, PerkinElmer, Boston, MA).

\section{RT-PCR}

Total RNA was isolated using the Chomczynski method (Chomczynski \& Sacchi 1987). cDNA was generated using reverse transcriptase (Superscript II, Invitrogen). TRAIL-R1 or DR4 sense: 5'-CCGCGGCCACACCCAGAAAGT-3', TRAIL-R1 or DR4 antisense: 5'-GTACATGGGAGGCAAGCAAACAAA-3' (generates a fragment of $415 \mathrm{bp}$ ); TRAIL-R2 or DR5 sense: 5'-GGGAGCCGCTCATGAGGAAGTTGG-3', TRAILR2 or DR5 antisense: 5'-GGCAAGTCTCTCTCCCAGCGTCTC- $3^{\prime}$ (generates a fragment of $181 \mathrm{bp}$ ); SOD type I sense: $5^{\prime}$-CTAGCGAGTTATGGCGAC3', SOD type I antisense: 5'-GAATGTTTATTGGGCGATC- $3^{\prime}$ (generates a fragment of $483 \mathrm{bp}$ ); 17 $\beta$-HSD type I sense: $5^{\prime}$-TATGCGAGAGTCTGGCGGTT-3', $17 \beta$-HSD type I antisense: $5^{\prime}$-TGCACTGGGCCGCACT- $3^{\prime}$ (generates a fragment of $80 \mathrm{bp}$ ); $17 \beta$-HSD type II sense: $5^{\prime}$-TTACCTGTGGATCAGAAGGCAGT-3', 17 $\beta$-HSD type II antisense: 5'-TTGCACAAAGCATGGCCA- $3^{\prime}$ (generates a fragment of $80 \mathrm{bp}$; BiosChile, Santiago, Chile). Semi-quantitative PCRs were performed from cDNA generated from cell lines and primary cultured cells maintained under maintenance conditions, using Taq polymerase (Invitrogen). As an internal control, primers amplifying a region of glyceraldehyde-3-phosphate dehydrogenase (GAPDH) were used to test the integrity of the starting cDNA as previously published (Sadarangani et al. 2007).

\section{Immunocytochemistry}

Cancer cell lines were resuspended in DMEM/F12 with $10 \%$ FBS and plated in $6 \mathrm{~cm}^{2}$ Petri dishes (tissue culture grade, Falcon, BD Labware, NJ, USA) containing glass cover slides. Once plated, the cell culture medium was changed to DMEM/F12 with 5\% charcoal-treated FBS for $24 \mathrm{~h}$. Cells were washed twice in PBS and fixed in $1 \%$ paraformaldehyde. Cells were washed again thrice in PBS and pseudoperoxidase activity blocked by $10 \mathrm{~min}$ incubation with $10 \%$ hydrogen peroxidase (Labvision, Cheshire, UK). Cells were washed as before and blocked in serum-free protein block solution (DAKO) for 30 min. TRAIL-R1/DR4 (BD Pharmingen, San Jose, CA, USA), TRAIL-R2/DR5 (Imgenex, San Diego, CA, USA), antibodies were added at a dilution of 1:250 for $18 \mathrm{~h}$. The slides were washed thrice and incubated with secondary anti-rabbit IgG peroxidase-labelled antibody (Kirkegaard Perry Labs Inc., Gaithersburg, MD, USA) for $1 \mathrm{~h}$ at room temperature. Covers were washed thrice and DAB Plus substrate (Labvision) added until a colour change was detected ( $\sim 10-20 \mathrm{~min})$. The reaction was stopped by washing in distilled water and cells were examined by light microscopy.

\section{Flow cytometry analysis}

Cell cycle distribution and the detection of a sub-G1 apoptotic peak were analysed by flow cytometry using propidium iodide DNA staining. Cells were harvested, centrifuged, washed and resuspended in a cold solution of $1 \mathrm{ml} 1 \times$ PBS and $4 \mathrm{ml} 70 \%$ ethanol. The cells were incubated overnight at $4{ }^{\circ} \mathrm{C}$, washed in $1 \times \mathrm{PBS}$ and resuspended in a solution of $250 \mu \mathrm{l}$ of propidium iodide $(50 \mu \mathrm{g} / \mathrm{ml})$ in $1 \times$ PBS and $1 \mu \mathrm{l}$ RNase $(20 \mu \mathrm{g} / \mathrm{ml}$; Gibson et al. 2002). Cells were incubated (protected from light) for $15 \mathrm{~min}$ at room temperature before analysis on a FACScan cytometer using the Cell Quest software (Becton Dickinson, Mountain View, CA, USA).

\section{Statistical analysis}

Statistical analysis is performed using the MannWhitney test, with $P<0.05$ regarded as statistically significant (GraphPad Instat 3 GraphPad Software Inc., San Diego, CA, USA). Data are represented as a percentage with respect to vehicle control. Standard deviation of the means is given from a minimum of three individual experiments performed, each consisting of five replicates. 


\section{Results}

\section{Apoptosis in response to oestrogen and oestrogen metabolites}

To determine if oestrogen and oestrogen metabolites altered cellular viability in cells of human female oestrogen responsive tissue origin, we incubated breast cancer cell lines (ZR-75 and MDA-231), endometrial cancer cell lines (Ishikawa and HEC1A) and a cervical cancer cell line (HeLa) for $48 \mathrm{~h}$ with $2 \mu \mathrm{M}$ concentrations of $\mathrm{E}_{2}, 2 \mathrm{ME}, 4 \mathrm{ME}, 2 \mathrm{OH}, 4 \mathrm{OH}$ or ethanol vehicle. As shown in Fig. 1A, analysis of cell viability by the MTS assay demonstrated that only $\mathrm{HeLa}$ cells were sensitive to treatment with $2 \mu \mathrm{M} \mathrm{E}_{2}$ after $48 \mathrm{~h}$. Treatment with $2 \mathrm{OH}, 4 \mathrm{OH}$ or $4 \mathrm{ME}$ had no effect on cellular viability at this concentration in any of the cell lines tested. However, 2ME elicited a significant reduction in cell viability in the endometrial and cervical but not in the breast cancer cell lines. To confirm that this reduction in cell viability by the MTS assay, which measures mitochondrial redox potential, was due to apoptosis, cell lysates were analysed for cleaved poly (ADP-ribose) polymerase (PARP) expression by western blotting. As shown in Fig. 1B, PARP cleavage occurred only in the presence of $2 \mathrm{ME}$, demonstrating that reduced cell viability was a consequence of increased apoptosis. Consequently, we chose the metabolite $2 \mathrm{ME}$ and selected the

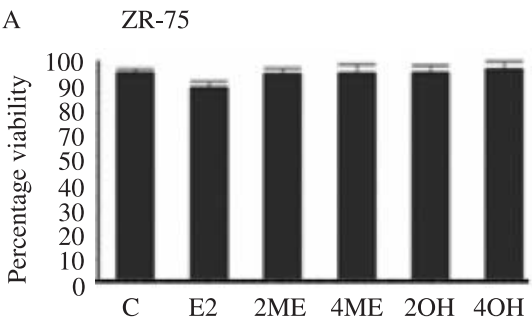

MDA-231
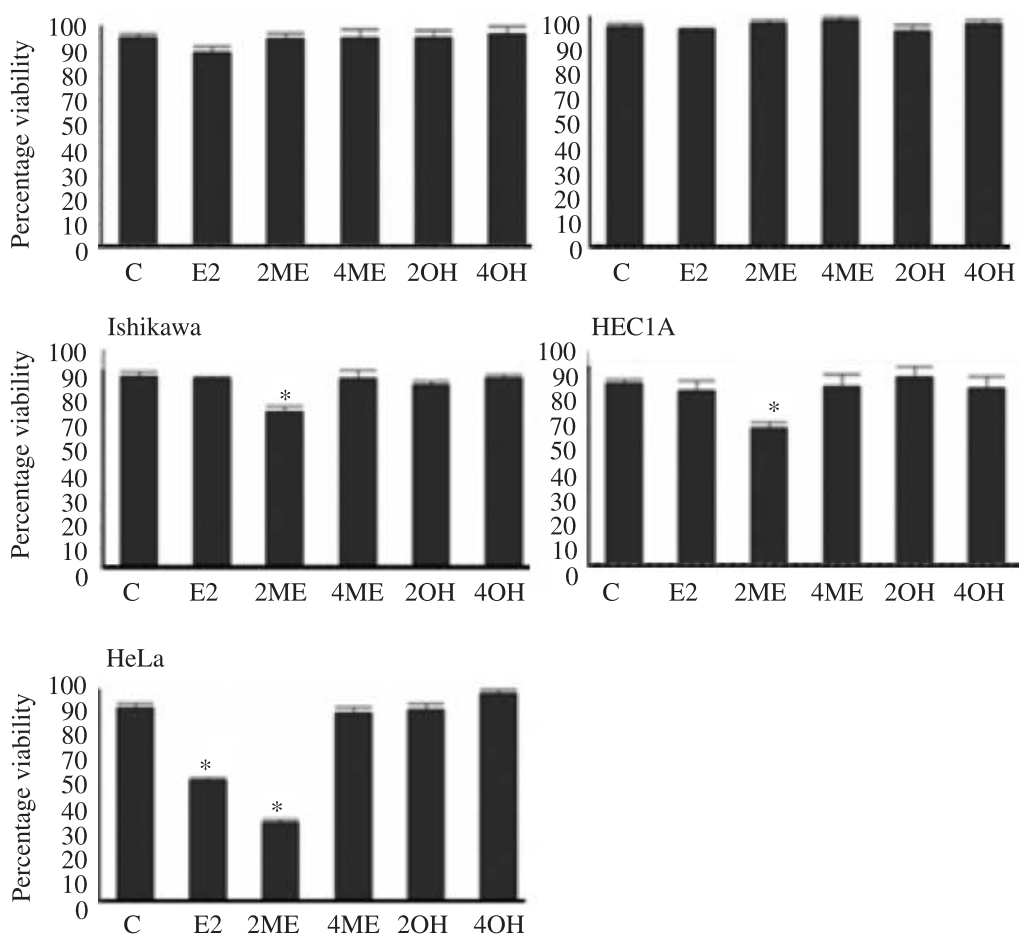

B

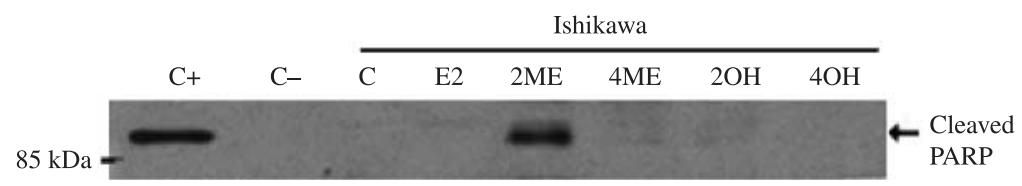

Figure 1 2-Methoxyoestradiol, but not other oestrogen metabolites, reduces cell viability and induces apoptosis in cancer cell lines of human reproductive tract origin. Cell viability was measured by the MTS assay and the data represented as a percentage with respect to control (ethanol, $\mathrm{C}$ ) in the presence or absence of $17 \beta$-oestradiol $\left(\mathrm{E}_{2}\right)$, 2-hydroxyoestradiol $(2 \mathrm{OH})$, 4-hydroxyoestradiol (4OH), 2methoxyoestradiol (2ME) and 4-methoxyoestradiol (4ME). Two breast cancer cell lines (ZR-75 and MDA-MB-231), two endometrial cancer cell lines (Ishikawa and HEC1A) and a cervical cancer cell line (HeLa) were tested. All concentrations were $2 \mu \mathrm{M}$ in ethanol vehicle. Standard deviation of the mean is shown from a minimum of three experiments performed, each consisting of five replicates. Mann-Whitney test statistical significance $\left({ }^{*}\right)$ was set at $P<0.05$ with respect to control (vehicle). (B) Western blot analysis in Ishikawa cells demonstrating the presence of cleaved PARP only in presence of 2-methoxyoestradiol (2ME) for $48 \mathrm{~h}$. Ishikawa cells treated with TRAIL $(200 \mathrm{ng} / \mathrm{ml})$ for $18 \mathrm{~h}$ were used as a control for apoptosis $(\mathrm{C}+)$. 
endometrial cancer cell lines, principally Ishikawa, for all further studies.

\section{Characterisation of 2ME-mediated apoptosis in the Ishikawa endometrial cancer cell line}

To characterise apoptosis in response to $2 \mathrm{ME}$, we first determined the optimal concentration for experimental use. As shown in Fig. 2A, a significant decrease in cellular viability was observed when cells were treated with $2 \mu \mathrm{M} 2 \mathrm{ME}$ and viability was further reduced upon treatment with $5 \mu \mathrm{M} 2 \mathrm{ME}$. Interestingly, $5 \mu \mathrm{M} 2 \mathrm{OH}$ was capable of significantly reducing cell viability (albeit $<5 \%$ ) in the Ishikawa and HEC1A cell lines (results not shown). With respect to $2 \mathrm{ME}$, analysis of PARP cleavage demonstrated that apoptosis was triggered at a much lower concentration $(1 \mu \mathrm{M})$ than that detected by the MTS assay (Fig. 2B). In accordance

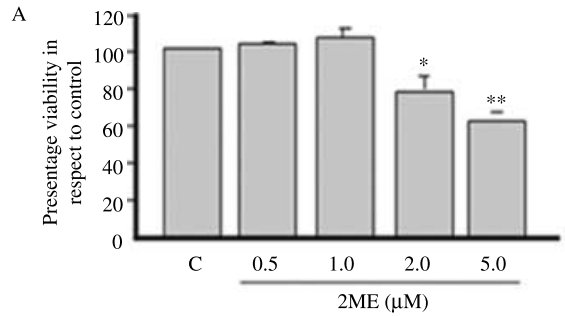

B
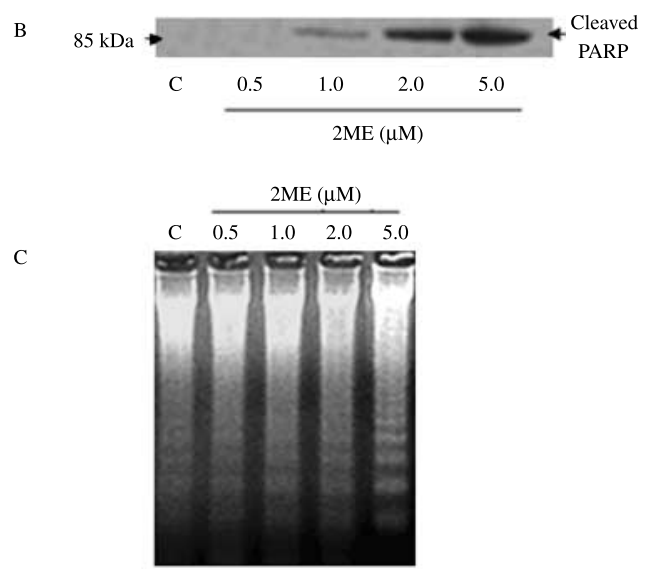

Figure 2 2-Methoxyoestradiol reduces Ishikawa cells viability and induces apoptosis in a concentration-dependent manner. $(A)$ Concentration-response curve in the presence of 2-methoxyoestradiol $(2 \mathrm{ME}, \mu \mathrm{M})$ for $48 \mathrm{~h}$ in Ishikawa cells. Cell viability was measured by the MTS assay and the data represented as a percentage with respect to control. Standard deviation of the means is shown from a minimum of three experiments performed, each consisting of five replicates. Mann-Whitney test ${ }^{\star} P<0.05$ with respect to control (vehicle), ${ }^{* \star} P<0.05$ with respect to previous concentration. (B) Western blot analysis in Ishikawa cells demonstrating the presence of cleaved PARP after the addition of varying concentrations of $2 \mathrm{ME}$ for $48 \mathrm{~h}$. (C) DNA fragmentation analysis of apoptosis induced by increasing concentrations of $2 \mathrm{ME}$ for $48 \mathrm{~h}$ in the Ishikawa cell line in comparison with vehicle-treated controls $(\mathrm{C})$. with this, Fig. 2C demonstrates an increase in DNA laddering in Ishikawa cells treated with increasing concentrations of $2 \mathrm{ME}$. Next, we examined the kinetics of response in Ishikawa cells treated with $5 \mu \mathrm{M} 2 \mathrm{ME}$. Figure $3 \mathrm{~A}$ shows that although loss of cell viability was not apparent upon $24 \mathrm{~h}$ treatment with $2 \mathrm{ME}$, the apoptotic machinery was already activated as demonstrated by PARP cleavage at this time point (Fig. 3B). Interestingly, PARP cleavage was no longer detectable after $72 \mathrm{~h}$ treatment, suggesting degradation of the protein as apart of the apoptotic process. We also examined the effect of $2 \mathrm{ME}$ on cell cycle progression in Ishikawa cells. A representative flow cytometry result is shown (Fig. 3C) after $48 \mathrm{~h} 2 \mathrm{ME}$ exposure, were the sub G0/G1 phase (apoptotic cells) is increased. To address this issue, in Fig. 3D, we performed time-course experiments where we demonstrate that $15 \%$ apoptosis was present after $24 \mathrm{~h} 2 \mathrm{ME}$ treatment, which may explain the appearance of PARP cleavage at this time in Fig. 3B. These results also confirm the results obtained by MTS at 48 and $72 \mathrm{~h}$ after $2 \mathrm{ME}$ exposure.

\section{Elucidation of the mechanism of 2ME-mediated cell death in the Ishikawa cell line}

In an effort to understand the mechanism of action, flow cytometry demonstrated that 2ME treatment increased the percentage of cells in the G2/M phase of the cell cycle before induction of the apoptotic process. Figure 3D shows that there is an accumulation in the G2/M phase of the cell cycle at $9 \mathrm{~h}$ before the first appearance of apoptosis at $18 \mathrm{~h}$. This increase in G2/M was sustained until $24 \mathrm{~h}$, after which the majority of the cells had entered the apoptotic process by $48 \mathrm{~h}$. To evaluate if the activation of the ER is required for $2 \mathrm{ME}$-mediated apoptosis, Ishikawa cells were pre-incubated with the pure ER antagonist ICI 182780 (ICI). However, ICI did not alter the ability of 2ME to induce apoptosis as seen by MTS assays (Fig. 4A), suggesting that the mechanism of action is via an ER-independent pathway. This observation was confirmed by flow cytometry (Fig. 4B), were no differences in the percentage of cells in the sub $G_{0} / G_{1}$ phase was observed. As seen in Fig. 1A, the cell line HeLa, which does not express ER, also undergoes apoptosis after 2ME exposure, adding further evidence that $2 \mathrm{ME}$ is utilising an ER-independent mechanism to bring about apoptosis. To determine if $2 \mathrm{ME}$-mediated apoptosis was utilising the intrinsic or extrinsic apoptotic pathways, we examined the activation of caspases. After $24 \mathrm{~h} 2 \mathrm{ME}$ exposure, we observed activation of caspase- 3 , the executor caspase, and the initiator caspases, caspase- 8 and caspase-9, which 
A

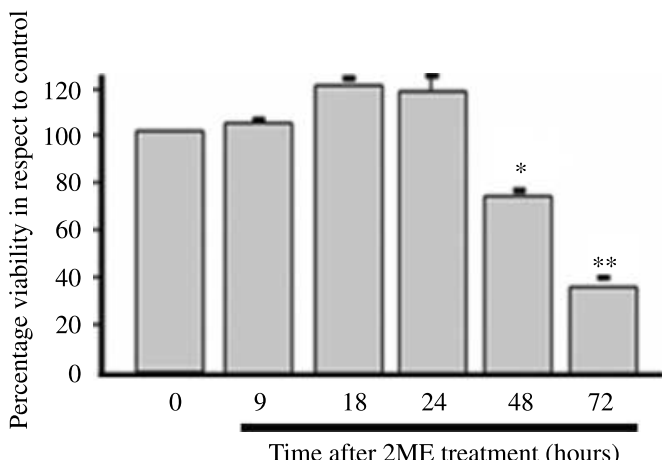

B

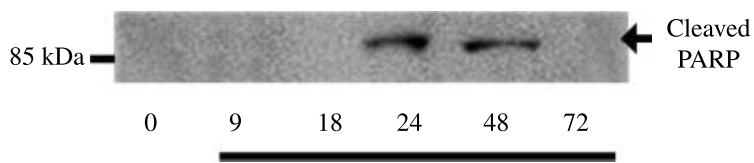

Time after 2ME treatment (hours)

$\mathrm{C}$
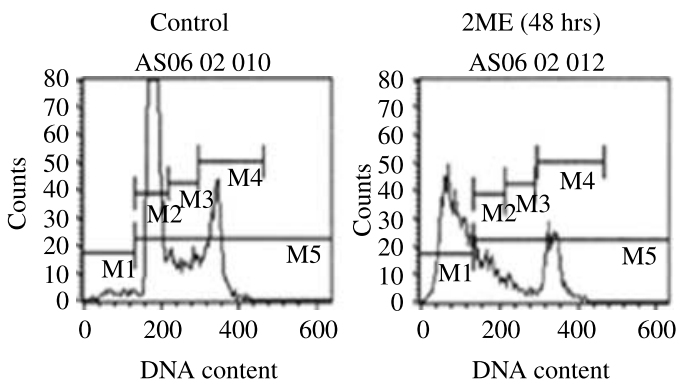

$\mathrm{D}$

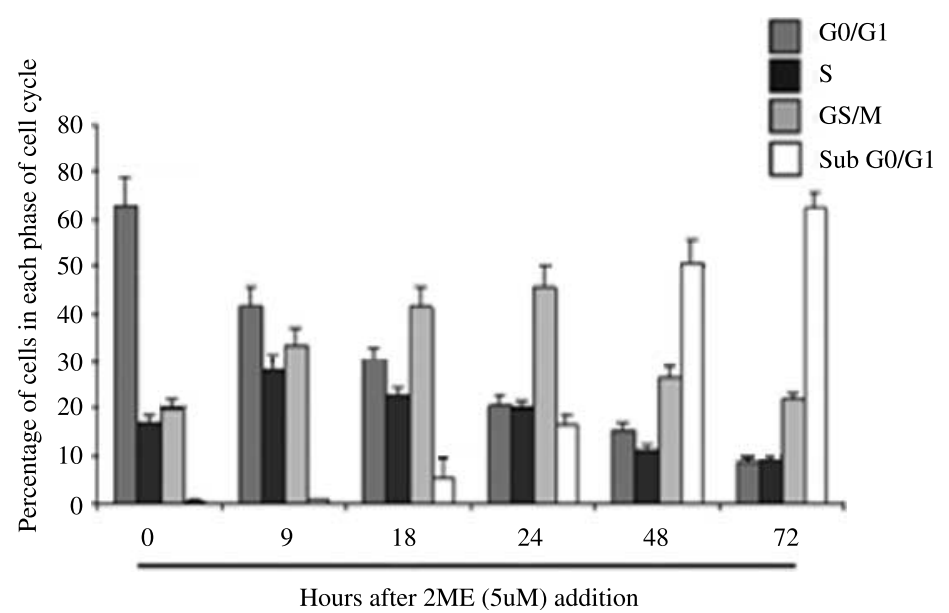

Figure 3 2-Methoxyoestradiol reduces Ishikawa cells viability and induces apoptosis in a time-dependent manner. (A) Time-course in Ishikawa cells in response to 2-methoxyoestradiol $(5 \mu \mathrm{M})$. Cell viability was measured by the MTS assay and the data represented as a percentage with respect to control (vehicle). Standard deviation of the means is shown from a minimum of three experiments performed, each consisting of five replicates. Mann-Whitney test set statistical significance at ${ }^{*} P<0.05$ with respect to control and previous time points, ${ }^{\star *} P<0.05$ with respect to $48 \mathrm{~h}$. (B) Western blot analysis of cleaved PARP after varying incubation times (hours) of 2-methoxyoestradiol (5 $\mu \mathrm{M})$ in Ishikawa cells. (C) Representative flow cytometry analysis of Ishikawa cells, demonstrating each phase of the cell cycle $(\mathrm{GO} / \mathrm{G} 1=\mathrm{M} 2, \mathrm{~S}=\mathrm{M} 3, \mathrm{G} 2 / \mathrm{M}=\mathrm{M} 4)$ and an apoptotic sub-GO/G1 peak (M1) after $2 \mathrm{ME}(5 \mu \mathrm{M})$ for $48 \mathrm{~h}$. (D) Graphical representation of the changes in the percentage of cells in cell cycle phases. 

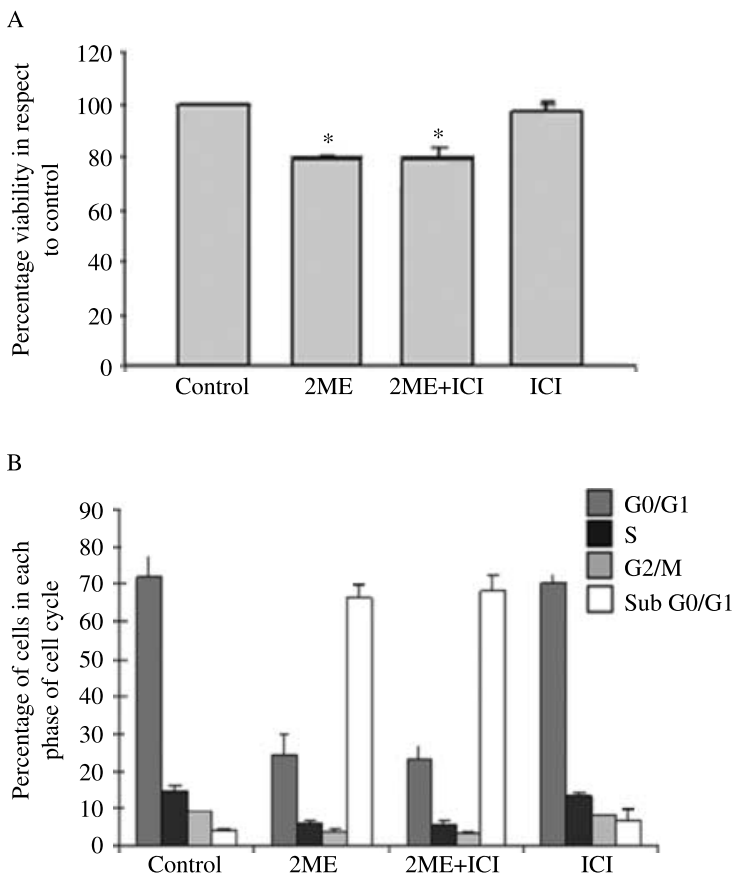

Figure 4 2-Methoxyoestradiol mediates apoptosis via an oestrogen receptor-independent pathway (A) Cell viability was measured by the MTS assay. The competitive oestrogen receptor antagonist ICI $182780(\mathrm{ICl}, 6 \mu \mathrm{M})$ was added for $30 \mathrm{~min}$ previous to 2-methoxyoestradiol (2ME, $5 \mu \mathrm{M})$ addition for $48 \mathrm{~h}$. Data represented as a percentage with respect to control (vehicle, $\mathrm{C}$ ). Standard deviation of the mean is shown from a minimum of three experiments performed, each consisting of five replicates. Mann-Whitney test set statistical significance at ${ }^{*} P<0.05$ with respect to control. (B) Graphical representation of the changes in the percentage of cells in cell cycle phases and apoptosis as measured by flow cytometry analysis.

respectively support the participation of the extrinsic and intrinsic pathway (Fig. 5A). To confirm caspase activation, Ishikawa cells were treated with general and specific caspase inhibitors. To further characterise the extrinsic and intrinsic pathways, Fig. 5B demonstrates that incubation with a general caspase inhibitor (Z-VAD) completely abolished the ability of $2 \mathrm{ME}$ to alter cell viability. Specific inhibition of caspase- 8 and -9 caused partial reversion of cell mortality, while inhibition of caspase-2 had not effect on 2MEmediated apoptosis. To further characterise the sequence of activation of the intrinsic and extrinsic pathways, we determined the temporal expression of key members of each pathway by western blot. To characterise one of the primary events in the apoptotic pathway, we examined Bid, a protein downstream of death-inducing signalling complex (DISC). Figure 6 demonstrates the loss of cytosolic Bid and the appearance of cleaved cytosolic Bid (t-Bid) at $6 \mathrm{~h}$ after 2ME exposure and its translocation to the

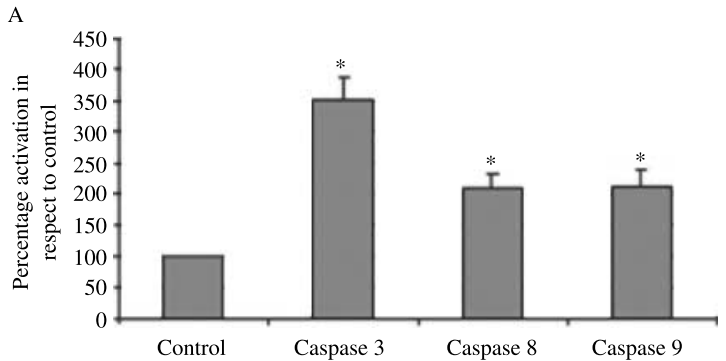

B

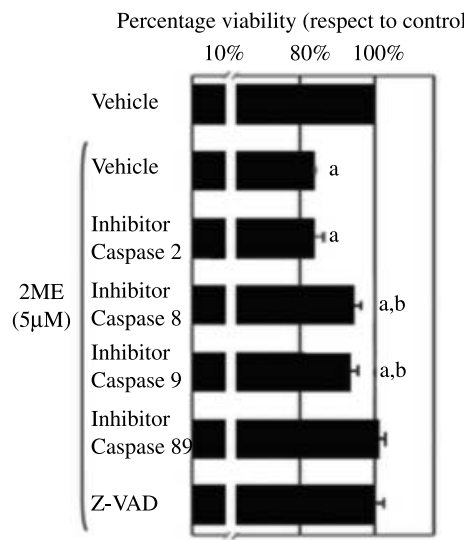

Figure 5 2-Methoxyoestradiol induces apoptosis via caspases 8 and 9 in Ishikawa cells. (A) Caspase activity assays (caspase$3,-8$ and -9$)$ in Ishikawa cells after the addition of $2 \mathrm{ME}(5 \mu \mathrm{M})$ for $24 \mathrm{~h}$. Cells in the absence of $2 \mathrm{ME}$ are set at $100 \%$.

Mann-Whitney test ${ }^{\star} P<0.05$ with respect to control. (B) Cell viability was measured by the MTS assay and the data represented as a percentage with respect to control (vehicle, C). Standard deviation of the mean is shown from a minimum of three experiments performed, each consisting of five replicates. The caspase inhibitors 2, 8, 9 and Z-VAD (all $50 \mu \mathrm{M}$ ) were added for $30 \mathrm{~min}$ previous to and for $24 \mathrm{~h}$ after 2-methoxyoestradiol (2ME, $5 \mu \mathrm{M})$ addition for $48 \mathrm{~h}$. Using the Mann-Whitney test, significance was set at $P<0.05$, with $a=$ significant with respect to vehicle, $b=$ significant with respect to 2-methoxyoestradiol $(5 \mu \mathrm{M})$ in Ishikawa cells.

mitochondrial membrane. We further demonstrate that Flip, a known DISC inhibitory protein, was also down-regulated. Analysis of the intrinsic pathway demonstrated an early loss of the cytosolic form of $\mathrm{Bad}$ and a translocation to the mitochondria at $3 \mathrm{~h}$. This coincided with cytochrome $\mathrm{C}$ and SMAC/Diablo release to the cytosol. No alteration was observed in AIF release in response to $2 \mathrm{ME}$. Analysis of antiapoptotic proteins acting at the mitochondrial level, demonstrated a reduction in Bcl-2 and Bcl-xL levels at later time points (9-18 h). In the case of Bcl-2, the loss from the mitochondria coincided with an increase in the cytosolic fraction at these time points. Further analysis of $\mathrm{Bcl}-2$ demonstrated a correlation between phosphorylation of this protein and loss of expression in the mitochondrial membrane (result not shown). 

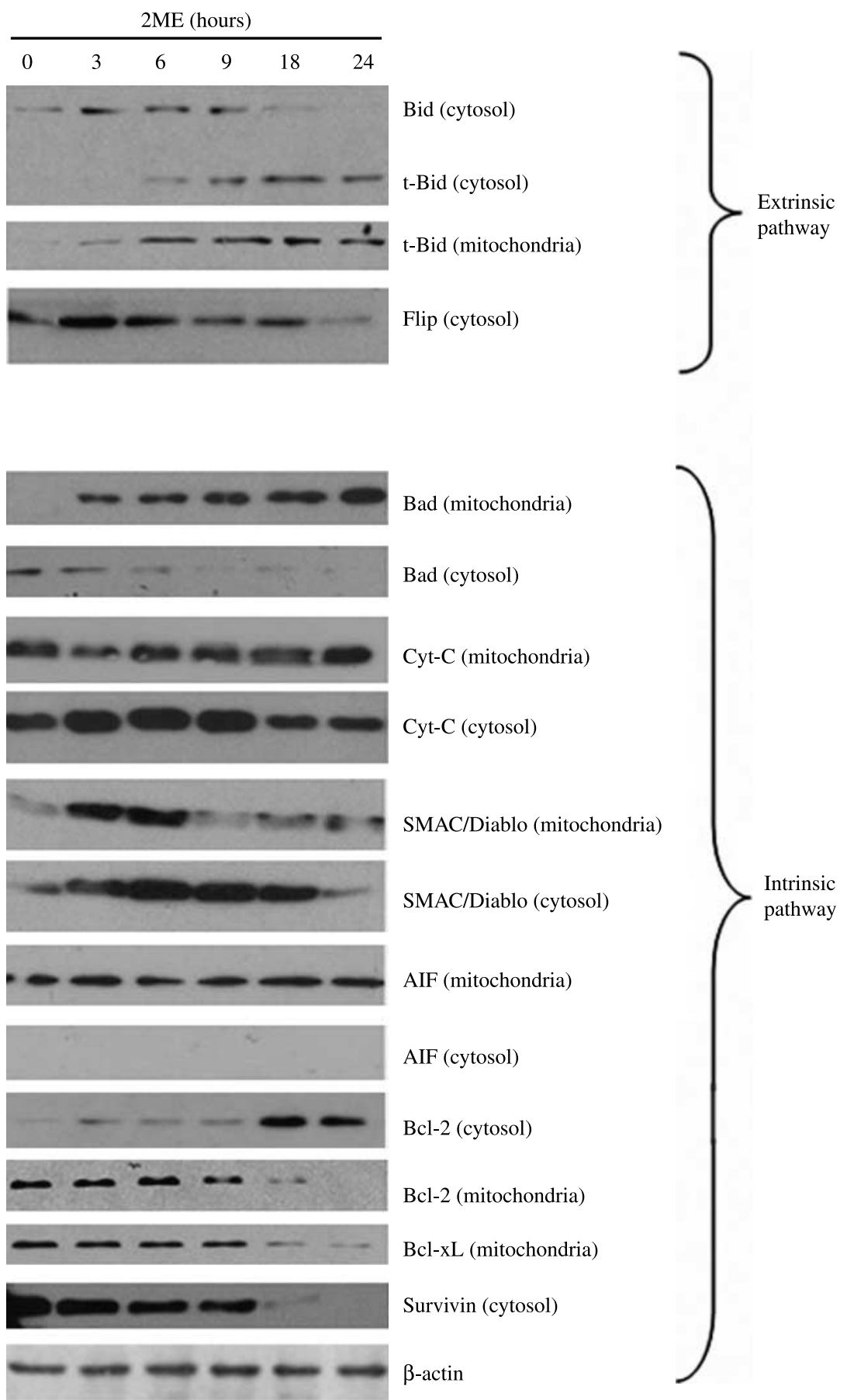

Figure 6 2-Methoxyoestradiol activation of the extrinsic and intrinsic apoptotic pathways. Western blot analysis of extrinsic and intrinsic apoptotic pathway proteins at varying time points after $2 \mathrm{ME}(5 \mu \mathrm{M})$ addition (hours). Western blot analysis of cytosolic and membrane factions was performed to examine the translocation of apoptotic proteins between the cytoplasm (cytosol) and the mitochondrial membrane (mitochondria).

Finally, we observed that Survivin, a downstream antiapoptotic protein, was also down-regulated during the same time frame. To explore the mechanism by which 2ME could activate the intrinsic apoptotic pathway, we explored the participation of ROS generation. RT-PCR was performed to examine alterations in the levels of superoxide dismutase (SOD) type $1 \mathrm{mRNA}$. Figure 7A shows a reduction in SOD type 1 mRNA with 
A

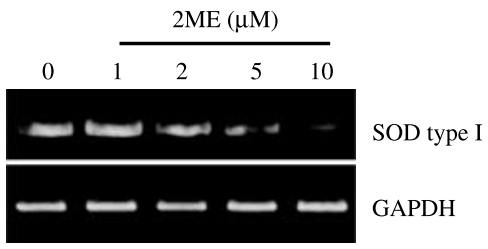

B

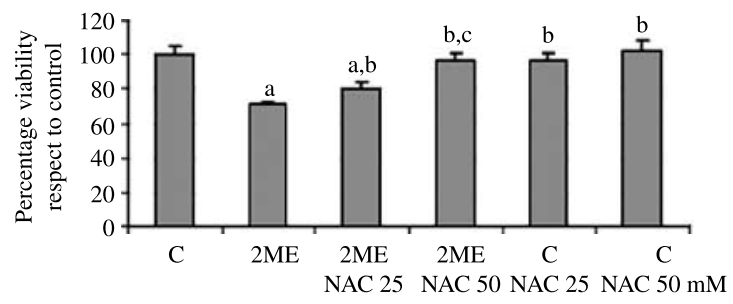

Figure 7 Down-regulation of superoxide dismutase type 1 by 2ME. (A). RT-PCR analysis of SOD type I mRNA in Ishikawa cells in response to varying concentrations of $2 \mathrm{ME}$ for $9 \mathrm{~h}$. GAPDH is shown as a loading control. (B). Cell viability was measured by the MTS assay and the data represented as a percentage with respect to control (vehicle, C). Standard deviation of the mean is shown from a minimum of three experiments performed, each consisting of five replicates. The anti-oxidant NAC was co-incubated at stated concentrations with $2 \mathrm{ME}(5 \mu \mathrm{M})$ for $48 \mathrm{~h}$. Using the Mann-Whitney test, significance was set at $P<0.05$, with $\mathrm{a}=$ significant with respect to vehicle, $\mathrm{b}=$ significant with respect to $2 \mathrm{ME}(5 \mu \mathrm{M})$ in Ishikawa cells.

increasing concentrations of $2 \mathrm{ME}$. As shown in Fig. 7B, the co-incubation with the anti-oxidant NAC reversed the reduction in cell viability mediated by $2 \mathrm{ME}$, substantiating the role of ROS generation in 2ME-mediated apoptosis. This result was also confirmed with pre-incubation with the anti-oxidant vitamin $\mathrm{C}$ (data not shown).

\section{ME action in cells originating from the human female reproductive tract}

Having characterised the action of $2 \mathrm{ME}$ in the endometrial cancer line Ishikawa, we determined if this action was conserved in another endometrial cancer cell line, HEC1A, and in primary cultures of malignant and non-malignant cells of the human female reproductive tract obtained from hysterectomy and bilateral salpingo-oophorectomy specimens. As shown in Fig. 8A, 2ME did not trigger apoptosis in cultured ovarian, cervical, fallopian tube or endometrial and stromal epithelial cells of non-malignant (normal) origin. In contrast, 2ME-mediated apoptosis in HEC1A cells, the cervical cancer cell line, HeLa, and in primary cell cultures of a primary cultured uterine sarcoma and one endometrial tumour. Some cultures were harvested for western blot analysis, which confirmed the absence of cleaved PARP in all
2ME-treated primary non-malignant cultures and its presence in cancer cell lines and primary cultured uterine sarcoma (Fig. 8B). To establish the possible differences in the sensibility to $2 \mathrm{ME}$, between normal and cancer tissues, we evaluated levels of the SOD type I mRNA. Figure 9 demonstrates the exclusive downregulation of SOD type $1 \mathrm{mRNA}$ levels in cancerous but normal cells of endometrial epithelium and cervical origin. This result reflects the regulation observed previously in the Ishikawa cell line (Fig. 7a). Given a previously reported anti-apoptotic role of the enzyme $17 \beta$-HSD, we evaluated the mRNA levels of type 1 and type II of this enzyme in our model of normal cancerous cells. As seen in Fig. 10, no apparent differences were observed in relation to the type I transcript (Fig. 10A), however, we found that tissues that undergo apoptosis in response to $2 \mathrm{ME}$ presented higher levels of $17 \beta$-HSD type II transcript.

\section{Combination of $2 \mathrm{ME}$ with known anti-tumoural agents}

The main disadvantage of currently used chemotherapy is that it affects both cancer and normal tissues. To evaluate this, we performed MTS assays to detect reduction in cell viability in normal cells obtained from hysterectomies of healthy patients. As showed in Fig. 11A, we observed a reduction in cell viability with chemotherapy currently used to treat endometrial cancer, such as DOX, PTX and CIS. In contrast to this, both the potential therapeutic agent TRAIL (Sadarangani et al. 2007) and 2ME or their combination did not reduce cell viability. Repeating this study in the endometrial cancer cell line Ishikawa, all chemotherapeutics, TRAIL and 2ME brought about a loss in cell viability (dark bars). When cells were previously exposed to $2 \mathrm{ME}$ for $24 \mathrm{~h}$, a significant decrease in cell viability was observed with TRAIL and PTX in comparison with each agent alone.

\section{Combination of $2 \mathrm{ME}$ with the apoptotic agent TRAIL}

Previous results from our laboratory demonstrated that the apoptotic potential of TRAIL in normal and malignant reproductive tissues mimics that of $2 \mathrm{ME}$ (Sadarangani et al. 2007). To confirm that no change in cell viability occurred in normal cells (Fig. 11A) and that the additive effect on cell viability (observed in Fig. 11B) was due to apoptosis, we performed flow cytometry analysis. As shown in Fig. 12, no apoptosis was detected in primary cultured endometrial epithelial cells. Furthermore, the 


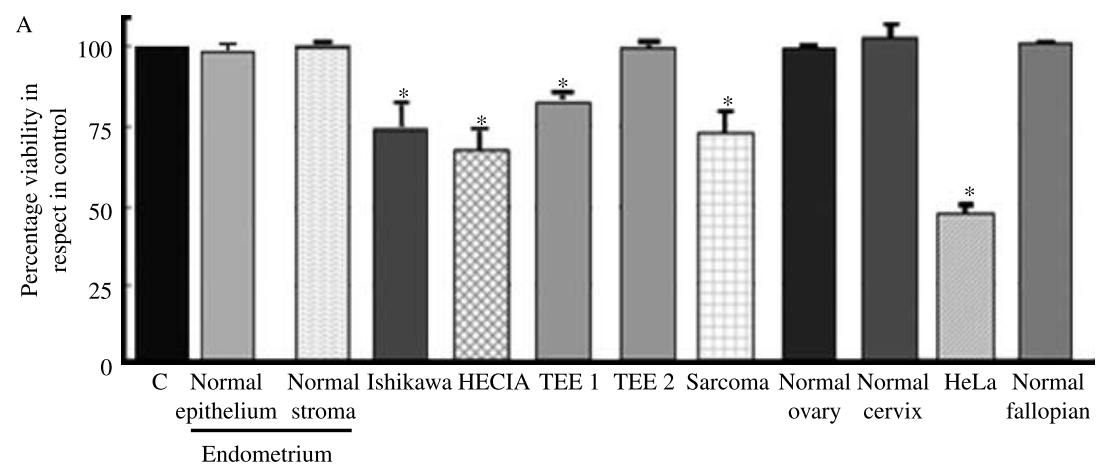

B

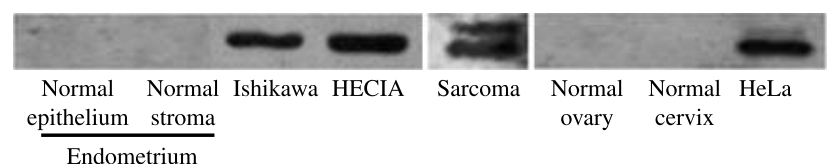

Figure 8 2-Methoxyoestradiol induces apoptosis in cancerous cells but not in normal cultured human cells of endometrial, ovarian, cervical or fallopian origin. MTS cell viability assays after 2-methoxyoestradiol (2ME, $5 \mu \mathrm{M})$ addition for $48 \mathrm{~h}$ in cultured normal endometrial epithelium, normal endometrial stroma, endometrial cancer cell lines Ishikawa and HEC1A, two cancerous endometrial epithelium (TEE), sarcoma (cancer originating in the endometrial stromal compartment), normal cultured ovarian cells, normal cultured cervical cells, a cervical cancer cell line (HeLa) and cultured normal epithelial cells of the fallopian tube. Data are represented as a percentage with respect to control. Standard derivation of the means is shown, each consisting of five replicates. Cell viability is set at $100 \%$ in the presence of vehicle (first bar, C). Statistical significance ${ }^{*}$ ) with respect to vehicle-treated control for each cell type was set at $P<0.05$ using the Mann-Whitney test. (B) Western blot analysis demonstrating the presence of cleaved PARP (apoptosis) in cancerous but not normal (healthy) cells in parallel cultures of the cells used in panel A.

combination of TRAIL and 2ME in Ishikawa cancer cells significantly increased cell death via apoptosis. To confirm that combined 2ME and TRAIL treatmentmediated apoptosis by caspase activation, the in vitro activity of caspase- 3 was analysed. Figure 13 shows that caspase- 3 is activated and that this activation is significantly increased with respect to both agents alone. Further confirmation of an additive effect is demonstrated by the increased cleavage of procaspase- 3 and the appearance of the $17 \mathrm{kDa}$ active caspase- 3 form in the presence of both apoptotic agents. This effect was also observed with procaspase- 9 , but not with procaspase- 8 .

\section{Mechanism by which 2ME enhances the apopto- tic effects of TRAIL}

We next evaluated a potential mechanism by which 2ME could enhance TRAIL-mediated apoptosis. Based on previous reports in the literature, we evaluated whether the TRAIL receptors TRAILR1/DR4 and TRAIL-R2/DR5 were up-regulated. As shown in Fig. 14A and B, 2ME up-regulates both DR4 and DR5 mRNA levels in the endometrial cancer cell lines Ishikawa and HEC1A. This result was further confirmed at the protein level by immunocytochem- istry in both endometrial cancer cell lines (Fig. 14C and data not shown). As we demonstrated that $2 \mathrm{ME}$ was increasing TRAIL receptors, we speculated that $2 \mathrm{ME}$ pre-treatment could lower the concentrations of TRAIL required to bring about the additive effect on apoptosis. To this end, Ishikawa cells were treated with 2ME $(5 \mu \mathrm{M})$ for $48 \mathrm{~h}$ with variable doses of TRAIL, ranging from 50 to $500 \mathrm{ng} / \mathrm{ml}$ for $18 \mathrm{~h}$. Under these conditions, pre-treatment with $2 \mathrm{ME}$ enhanced the sensitivity of Ishikawa cells to lower concentrations of TRAIL and increasing the concentration of TRAIL

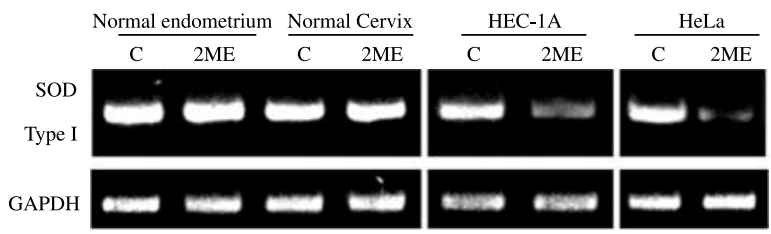

Figure 9 Differing regulation of superoxide dismutase type 1 by $2 \mathrm{ME}$ in cancerous and normal cells of human endometrial and cervical origin. (A). RT-PCR analysis of SOD type I mRNA in primary cultured normal human endometrial and cervical epithelium, HEC1A endometrial cancer cells and HeLa cervical cancer cells in response to 9 -h treatment with $2 \mathrm{ME}(5 \mu \mathrm{M})$. GAPDH is shown as a loading control. 


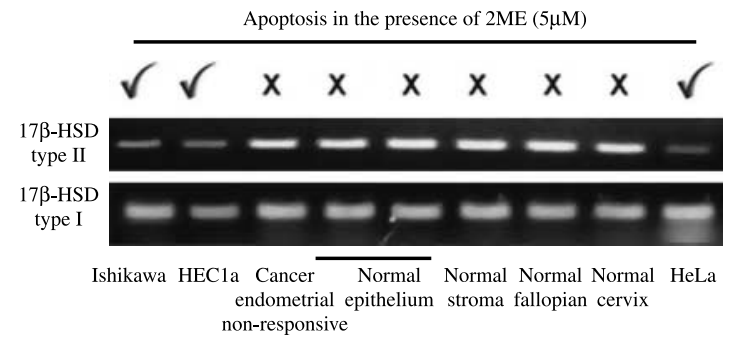

Figure 10 Differing expression of $17 \beta-H S D$ type II in cancerous and normal cells of the human female reproductive tract. RT-PCR analysis of $17 \beta$-HSD type I and type II mRNA in primary cultures of stated origin. The presence $(\checkmark)$ or absence $(\times)$ of apoptosis mediated by $2 \mathrm{ME}(5 \mu \mathrm{M}$ for $48 \mathrm{~h})$ in co-cultured cells is presented.

beyond $50 \mathrm{ng} / \mathrm{ml}$ did not further enhance loss of cell viability (Fig. 15).

\section{Discussion}

Endometrial cancer is the most common invasive neoplasm of the female genital tract and one of the
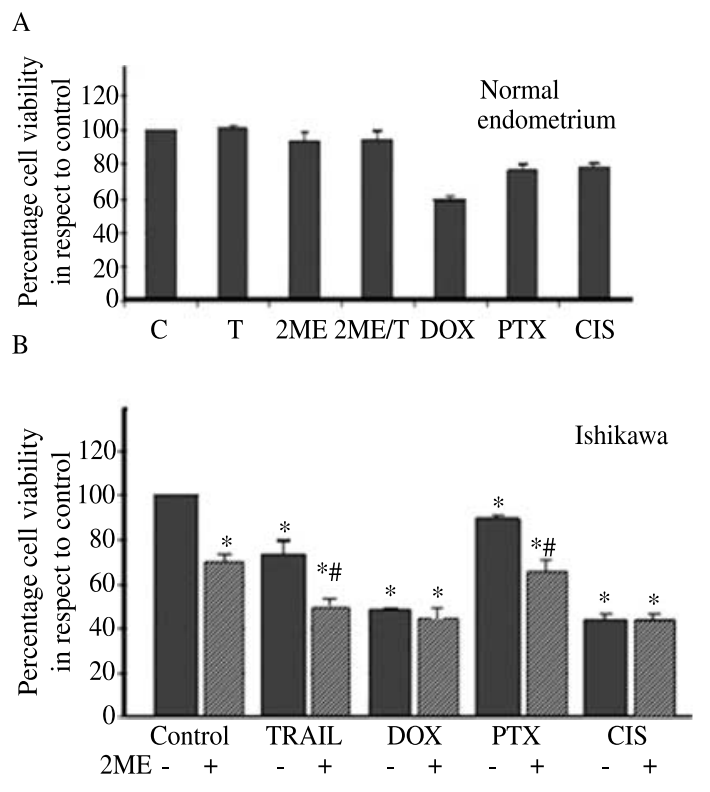

Figure $112 \mathrm{ME}$ and TRAIL mediate apoptosis in endometrial cancer cells without the reduction in normal cell viability observed with conventional chemotherapies. Cell viability was measured by the MTS assay in normal cultured human endometrial epithelial cells (A), and the Ishikawa endometrial cancer cell line (B). In both panels, cells were treated with ethanol vehicle (C), TRAIL $200 \mathrm{ng} / \mathrm{ml}$ for $18 \mathrm{~h}, 2 \mathrm{ME}$ for $48 \mathrm{~h}$ or $2 \mathrm{ME}$ for $48 \mathrm{~h}$ with TRAIL addition occurring $18 \mathrm{~h}$ before the end of the experiment (TRAIL+2ME). The chemotherapeutics, Doxorubicin (DOX, $5 \mu \mathrm{M})$, Paclitaxel (PTX, $5 \mu \mathrm{M})$ and Cisplatin (CIS, $5 \mu \mathrm{M})$, were administered for $48 \mathrm{~h}$. Using the Mann-Whitney test, statistical significance in change in cell viability with respect to vehicletreated control $\left(^{*}\right)$ and individual administration (\#) for each drug was set at $P<0.05$.

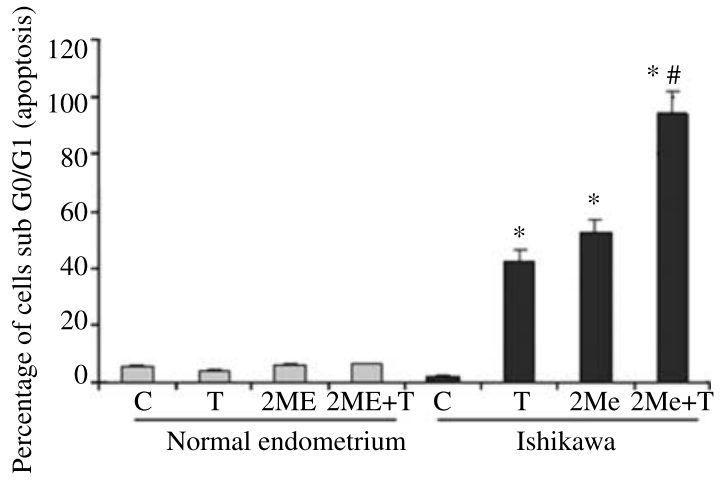

Figure 12 Flow cytometry analysis of 2ME- and TRAIL-mediated apoptosis in Ishikawa cells but not normal endometrial epithelium. Percentage of Ishikawa cells or primary cultured human endometrial epithelium (normal endometrium) in the sub G0/G1 fraction (apoptotic) are represented after treatment with ethanol vehicle (C), TRAIL $200 \mathrm{ng} / \mathrm{ml}$ for $18 \mathrm{~h}, 2 \mathrm{ME}$ for $48 \mathrm{~h}$ or $2 \mathrm{ME}$ for $48 \mathrm{~h}$ with TRAIL addition occurring $18 \mathrm{~h}$ before the end of the experiment (TRAIL+2ME). Using the Mann-Whitney test, statistical significance in change in cell viability with respect to vehicle-treated control $\left(^{*}\right)$ and individual administration (\#) for each drug was set at $P<0.05$.

most frequently diagnosed cancers (Carter \& Pather 2006). There exists a strong association between the endometrial cancer risk and oestrogen exposure, primarily due to the mitotic role of oestrogen during the follicular stage of the menstrual cycle (Amant et al. 2005, Carter \& Pather 2006), however, growing evidence is demonstrating that oestrogen metabolites alone at higher than physiological concentrations may display oestrogenic, anti-oestrogenic and/or unique behaviour. The objective of this study was to determine the effect of oestrogen metabolites on the oestrogenresponsive normal and cancerous human endometrium and on other reproductive target tissues. Herein, we demonstrate that endometrial and cervical cancer cells, but not primary cultured cells, corresponding to respective normal tissue undergo apoptosis in response to the oestrogen metabolite, 2ME. Similarly, a mild $(5 \%)$ reduction of cell viability was observed with $2 \mathrm{OH}$ in certain cell lines, but only at the highest concentration tested and this could be explained by differences in the expression of the enzymes that control the biogenesis of the oestrogen metabolites, such as COMT (Merriam et al. 1980). Our observation that $E_{2}$ at high concentrations can cause apoptosis in HeLa cells, a cervical carcinoma cell line, has also been reported previously and thus not pursued further in this report (Acconcia et al. 2005). Physiological (picomolar) or low pharmacological concentrations of 2ME did not trigger cell death in Ishikawa cells, suggesting that the endogenous $2 \mathrm{ME}$ production does not act as a pro-apoptotic stimulus. However, at higher 
A

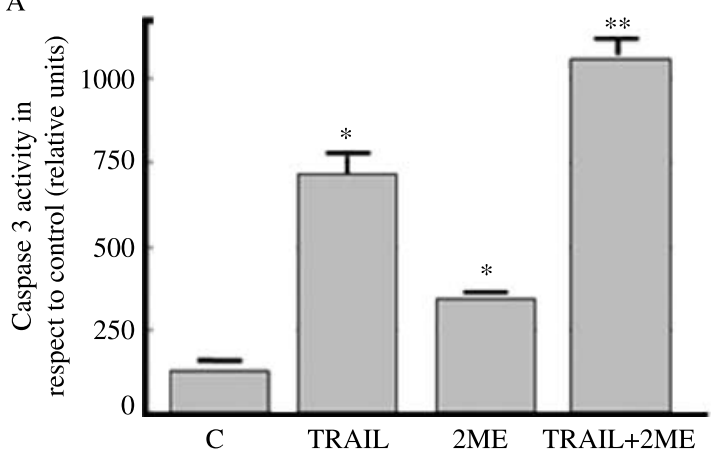

B

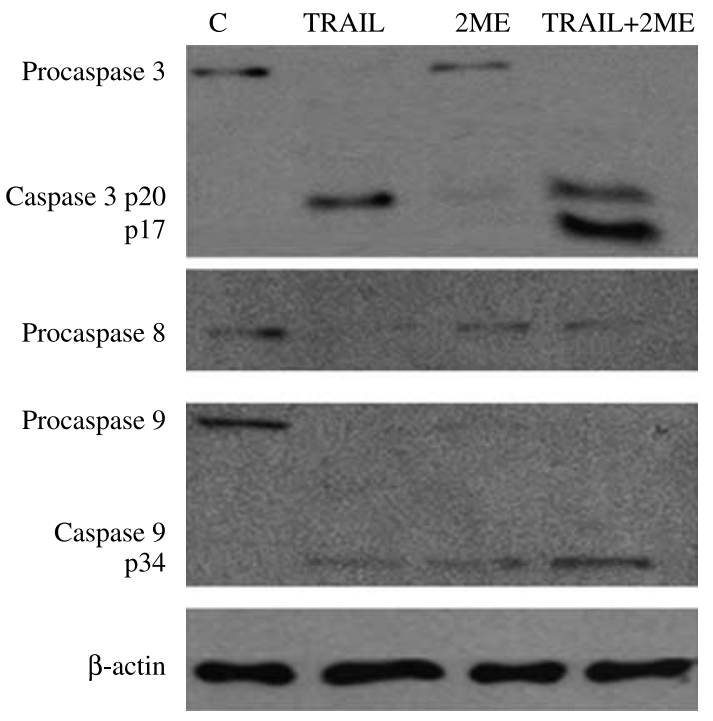

Figure 13 Additive activation of caspases by combined 2ME and TRAIL treatment. (A) Caspase-3 activity in the Ishikawa endometrial cancer cell line. Cells were treated with ethanol vehicle (C), TRAIL $200 \mathrm{ng} / \mathrm{ml}$ for $18 \mathrm{~h}$, 2-methoxyoestradiol (2ME) for $48 \mathrm{~h}$ or $2 \mathrm{ME}$ for $48 \mathrm{~h}$ with TRAIL addition occurring $18 \mathrm{~h}$ before the end of the experiment (TRAIL +2ME). Data are represented as a percentage with respect to control. Standard deviation of the mean is shown from a minimum of three experiments performed, each consisting of five replicates. Mann-Whitney test ${ }^{*} P<0.05$ with respect to control (vehicle), ${ }^{* \star} P<0.05$ with respect to individual treatments. (B) Western blot analysis of procaspase- $3,-8$ and -9 cleavage in the presence of above-stated treatments. $\beta$-actin is used as a loading control.

concentrations $(1-5 \mu \mathrm{M}), 2 \mathrm{ME}$ induces cell death in endometrial and cervical cancer cells, providing further support for its therapeutic potential in reproductive tract malignancies.

The mechanism by which $2 \mathrm{ME}$ mediates apoptosis is accompanied by an increase in the number of cells in the $\mathrm{S}$ or $\mathrm{G} 2 / \mathrm{M}$ phase of the cell cycle, as has been previously reported in other cancer cell types (Qadan et al. 2001) and the endometrial cancer cell line, HEC1A ( $\mathrm{Li}$ et al. 2007). Furthermore, Zhou et al. (2004) reported in nasopharyngeal carcinoma cells that $2 \mathrm{ME}$-induced cell cycle arrest at $\mathrm{G} 2 / \mathrm{M}$ phase and that apoptosis was associated to Bcl-2 down-regulation. Herein, in the most detailed study of $2 \mathrm{ME}$-mediated apoptosis to date in the reproductive tract, we demonstrate an apoptotic effect that is AIF independent and caspase activation dependent, involving the utilisation of both the intrinsic and extrinsic pathways. Our results suggest that $2 \mathrm{ME}$ is activating both the intrinsic pathway, as demonstrated by the early activation of the pro-apoptotic components of the intrinsic pathway (BAD, Cyt-c, SMAC/Diablo), followed by later down-regulation of the anti-apoptotic proteins Bcl-2 and Bcl-xL. To examine a mechanism by which $2 \mathrm{ME}$ could activate the intrinsic pathway, we examined the hypothesis that $2 \mathrm{ME}$ was generating reactive agent species and thus damage the mitochondrial membrane. We demonstrated that $2 \mathrm{ME}$ down-regulates anti-oxidant enzyme SOD and that 2ME-mediated apoptosis is completely reversed by the anti-oxidants (NAC and Vitamin-C). Activation of the extrinsic pathway is demonstrated by cleavage of procaspase-8, Bid cleavage and down-regulation of the extrinsic inhibitor FLIP.

Although $2 \mathrm{ME}$ binds to ER $\alpha$ and ER $\beta$ with 500- and 3200 -fold lower affinities respectively, than that of $E_{2}$, $2 \mathrm{ME}$ has been demonstrated previously to mediate cell fate through this union (LaVallee et al. 2002). Despite the presence of both ER $\alpha$ and ER $\beta$ in Ishikawa cells, competitive inhibition with an ER binding antagonist did not alter 2ME-mediated apoptosis. Furthermore, a receptor-independent mechanism of action was confirmed by the ability of $2 \mathrm{ME}$ to mediate apoptosis in an ER-negative cancer cell line (HeLa). Although previously reported in certain breast cancer cell lines, the mechanism of action of $2 \mathrm{ME}$ in endometrial cancer is currently under investigation; however, the use of an ER-independent pathway for $2 \mathrm{ME}$ action raises the possibility of using $2 \mathrm{ME}$ as an effective treatment for advanced (more aggressive) endometrial and cervical cancers, which tend to be hormone receptor negative (Maeda et al. 2002).

A requirement for any cancer treatment is that the potential agent has greater toxicity on cancerous cells than on corresponding normal tissue. Our results clearly show that $2 \mathrm{ME}$ does not alter cell viability of primary cultured endometrial cells or corresponding reproductive tract tissue, such as the endometrial stroma, ovary, cervix and fallopian tube epithelium. This further supports the use of $2 \mathrm{ME}$ as a treatment for endometrial-derived tumours. A recent report by Li et al. (2007) demonstrated that oral administration of $2 \mathrm{ME}$ did not bring about death of a xenograph of the endometrial cell line HEC1A in SCID mice. However, this may be due to the problems of $2 \mathrm{ME}$ metabolism in 
A

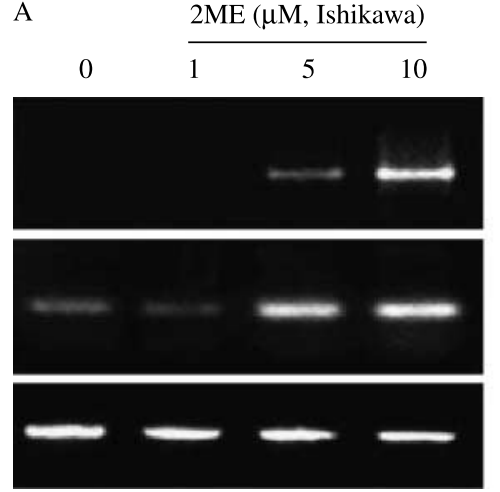

$\mathrm{C}$
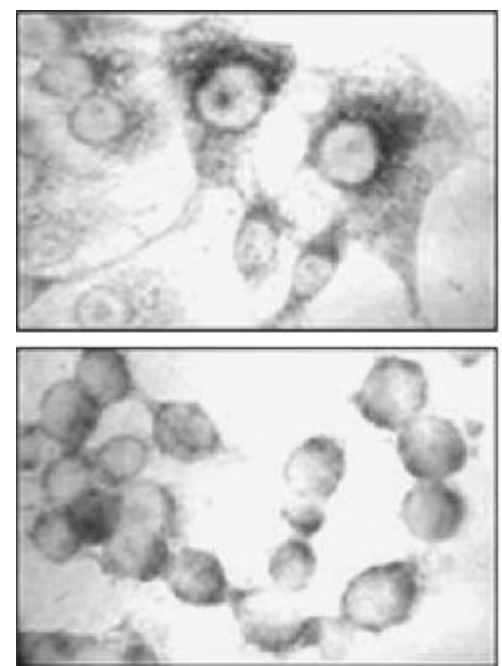

B

$0 \quad \frac{2 \mathrm{ME}(\mu \mathrm{M}, \mathrm{HEC} 1 \mathrm{~A})}{5}$

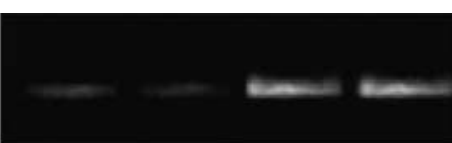

DR4
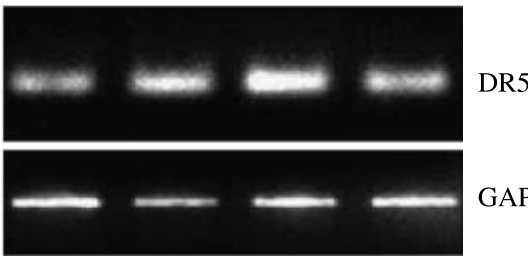

GAPDH

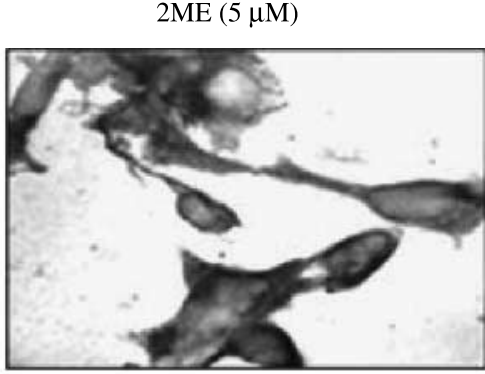

DR4

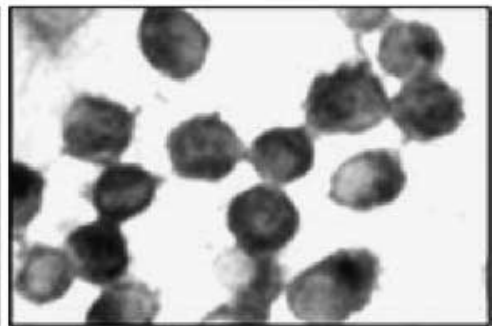

DR5

Figure 14 2-Methoxyoestradiol up-regulates TRAIL Receptors, DR4 and DR5 in endometrial cancer cell lines. RT-PCR demonstrating an increase in DR4 and DR5 mRNA with increasing concentrations of 2ME for $9 \mathrm{~h}$ in Ishikawa (A) and HEC1A (B) endometrial cancer cell lines. (C) Immunocytochemistry demonstrating that the increases in mRNA levels are mirrored at the protein level after $24 \mathrm{~h}$ of $2 \mathrm{ME}$ treatment in Ishikawa.

the liver. We present results demonstrating that $2 \mathrm{ME}$ kills cancer cells only at high concentrations (micromolar), which would suggest that the oral administration used by Li et al. (2007) was not arriving at the tumour site at sufficient concentrations. With respect to the treatment of endometrial cancer, the principal sites of primary invasion are the uterine wall (from endometrium through myometrium to serous layer), pelvic and/or periaortic lymph nodes and the peritoneum. We propose that the direct local administration of 2ME into the uterine lumen or the peritoneal cavity could bypass any concerns that have been raised concerning the metabolism and effective concentration of 2ME (Utsumi et al. 2005). Despite examining the effects of $2 \mathrm{ME}$ on primary cultured uterine-derived tumours, no major conclusions can be obtained, due to a limiting number of cases. However, interestingly, a uterine sarcoma (a type of cancer that is currently resistant to actual chemotherapy) underwent apoptosis after 2ME exposure suggesting a new therapeutic approach to this type of malignant and untreatable tumour. A further requisite of a potential cancer treatment is that it is more effective than the currently available treatment or possesses the same efficiency but with less side effects. Herein, we demonstrate that $2 \mathrm{ME}$ displays similar reductions in cell viability of endometrial cancer cells that the conventional chemotherapies currently used, while showing minimal loss in cell viability to normal cells. This effect is further enhanced by the co-treatment with the potential apoptotic cancer drug TRAIL, which we previously characterised in endometrial tissue (Sadarangani et al. 2007). 


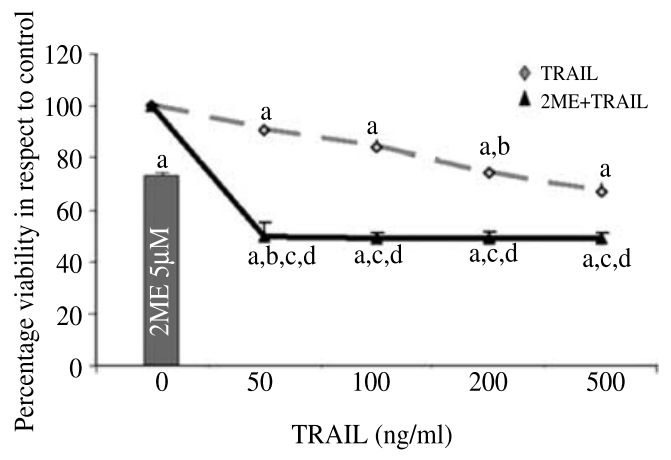

Figure 15 2-Methoxyoestradiol sensitises Ishikawa endometrial cancer to TRAIL-mediated apoptosis. Cell viability was measured by the MTS assay in response to the apoptotic drugs $2 \mathrm{ME}$ and TRAIL. TRAIL concentration was varied between 50 and $500 \mathrm{ng} / \mathrm{ml}$ for $18 \mathrm{~h}$ after the presence (triangle) or absence (diamonds) of $2 \mathrm{ME}$ fixed at $5 \mu \mathrm{M}$ was added $24 \mathrm{~h}$ previously. The grey bar represents $2 \mathrm{ME}(5 \mu \mathrm{M})$ alone for $48 \mathrm{~h}$. Data are represented as a percentage with respect to control and standard deviation of the mean is shown from a minimum of three experiments performed, each consisting of five replicates. Using the Mann-Whitney test, significance was set at $P<0.05$, with $a=$ significant with respect to vehicle, $b=$ significant with respect to previous lower concentration, $c=$ significant with respect to the matched concentrations of the same drug alone, $d=$ significant with respect to fixed-drug concentration (black bar).

This suggests that endometrial cancer could be refractory to this combination of drugs without detriment to normal tissue. As with $2 \mathrm{ME}$ alone, further studies are required to determine whether or not the presence of TRAIL and 2ME could have an additive effect and thus beneficial outcome on the majority of cancers of endometrial origin. Supporting this fact, we show that the combination of 2ME and TRAIL is as effective as the combination of $2 \mathrm{ME}$ and actual chemotherapy, thereby supporting the use of combining both agents. Interestingly, a fixed concentration of $2 \mathrm{ME}$, when added to the endometrial cancer cell line, reduced the concentration of TRAIL required to achieve maximum cell death. This is appealing to cancer treatments as TRAIL, although displaying no significant loss in cell viability in our model, has been reported to have mild side effects in clinical studies. Thus, the pre-treatment with $2 \mathrm{ME}$ may reduce or eliminate these TRAIL side effects without altering (and potentially increasing) the response to TRAIL on tumour cells. Furthermore, pre-treatment with 2ME also sensitised the endometrial cancer cells to the effect of PTX.

In relation to the mechanism of action of the TRAIL and $2 \mathrm{ME}$ interaction, we demonstrate that in accordance with previous reports in other tissue (Basu et al. 2006), that 2ME is increasing the levels of TRAIL receptors DR4 and DR5, thus potentially increasing the response to the TRAIL ligand. With respect to the action of 2ME and TRAIL, it is not clear if an additive effect of TRAIL and 2ME is due to separate apoptotic pathways or the sensitisation of common pathway. A differing activation of caspase-3 is present and we previously (Sadarangani et al. 2007) demonstrated that TRAIL brings about a loss in cell viability at $18 \mathrm{~h}$, while herein $48 \mathrm{~h}$ is required in the presence of $2 \mathrm{ME}$. However, neither inhibitors of caspase- 8 and -9 completely reverse the apoptotic effects of $2 \mathrm{ME}$, but caspase-8 inhibitor reversed completely the effects of TRAIL. These results suggest an activation of the intrinsic pathway by TRAIL, possibly via the activation of the extrinsic pathway (caspase- 8 , then BID), while $2 \mathrm{ME}$ activates both pathways.

A principal observation of this work is that $2 \mathrm{ME}$ lowers cell viability in cancerous but not normal cells. To address a mechanism behind this observation, we analysed the possible differences in SOD type I, the regulation of which we had previously shown to be altered by $2 \mathrm{ME}$ in Ishikawa cells. Interestingly, $2 \mathrm{ME}$ does not reduce SOD type I mRNA levels in primary cultured normal endometrial and cervical cells (as opposed to corresponding cancer cells). This suggests that these non-cancerous cells are exposed to less ROS and maybe less susceptible to undergo apoptosis via the intrinsic pathway. Conversely, $2 \mathrm{ME}$, by lowering the anti-oxidant (SOD type I) in cancer cells, may cause ROS accumulation and thus the inevitable entry into apoptosis. In addition, confirming our results, using complementary DNA micro arrays and biochemical approaches, it has been shown (Huang et al. 2000) that 2-carbon modifications (2-OH and 2-OCH3) induces apoptosis in human leukaemia cells but not normal lymphocytes via inhibition of the SOD type I. This inhibition causes the accumulation of cellular ROS species and leads to free radical-mediated damage to mitochondrial membranes specifically in cancer cells.

A further previously speculated mechanism for the selective effect of $2 \mathrm{ME}$ on cancerous over normal cells is a differing expression of 17 $\beta$-HSD isoforms. A preferential balance for type I, as opposed to the type II isoform, has prognostic significance in breast cancer and that altered expression of these enzymes is correlated with breast cancer progression (Gunnarsson et al. 2001), possibly due to the rapid conversion of $2 \mathrm{ME}$ to the inactive metabolite 2-methoxyoestrone (Liu et al. 2005). We demonstrate in the endometrium that an increase in this enzyme may have a role in $2 \mathrm{ME}$ insensitivity based on the observation that $17 \beta$-HSD type II mRNA levels are higher in the normal (and non-sensitive) than in our cancerous cells and that Newman and colleagues (Day et al. 2006) demonstrated a correlation between $17 \beta$ HSD type II mRNA levels and protein activity. 
Currently, experiments are on the way to test the hypothesis that Ishikawa cells stably transfected with $17 \beta$-HSD type II are more resistant to $2 \mathrm{ME}$ treatment.

$2 \mathrm{ME}$ is already being considered as a cancer therapeutic for breast cancer (Lakhani et al. 2003). However, despite ongoing clinical trials reporting an absence of grade 4 toxicity and only minor grade 3 toxicity in relation to disease progression, less than encouraging beneficial effects on breast cancer progression are being presented (Lakhani et al. 2003). As our results, albeit in vitro, also demonstrate minimal effects on breast cancer cells, but significantly reduced viability of endometrial cancer cells, we postulate that 2ME alone or in combination with TRAIL would have a beneficial outcome in clinical trials of patients presenting with uterine-derived cancers. Furthermore, the metabolism of $2 \mathrm{ME}$ in the liver is also hindering the application of this drug; however, due to the nature of endometrial cancer and its principal invasive sites, drug administration could occur directly into the uterine lumen and/or the peritoneum thus circumventing the problem of drug metabolism.

\section{Acknowledgements}

At the Pontificia Universidad Católica de Chile, we acknowledge Drs Croxatto and Orihuela for their advice and help with 2ME; Dr David Mayerson, member of Gynaecologic Oncology Unit at the Department of Obstetrics and Gynaecology for their clinical advice and sample collection; all the pathologists working at the Department of Pathology for their critical review of the samples collected; Dr Lipkowitz at the NIH, USA for the use of GST-TRAIL and Dr Lam at Imperial College London for his assistance with flow cytometry. The authors declare that there is no conflict of interest that would prejudice the impartiality of this scientific work.

\section{Funding}

This work was supported by a grant from the Wellcome Trust GR071469 (GIO) and the Chilean national science grants FONDECYT 1060495(GIO) and 1050744 (MC).

\section{References}

Acconcia F, Totta P, Ogawa S, Cardillo I, Inoue S, Leone S, Trentalance A, Muramatsu M \& Marino M 2005 Survival versus apoptotic 17beta-estradiol effect: role of ER alpha and ER beta activated non-genomic signaling. Journal of Cellular Physiology 203 193-201.
Amant F, Moerman P, Neven P, Timmerman D, van Limbergen E \& Vergote I 2005 Endometrial cancer. Lancet 366 491-505.

van Aswegen CH, Purdy RH \& Wittliff JL 1989 Binding of 2-hydroxyestradiol and 4-hydroxyestradiol to estrogen receptors from human breast cancers. Journal of Steroid Biochemistry 32 485-492.

Basak C, Pathak SK, Bhattacharyya A, Pathak S, Basu J \& Kundu M 2005 The secreted peptidyl prolyl cis,transisomerase HP0175 of Helicobacter pylori induces apoptosis of gastric epithelial cells in a TLR4- and apoptosis signal-regulating kinase 1-dependent manner. Journal of Immunology 174 5672-5680.

Basu A, Castle VP, Bouziane M, Bhalla K \& Haldar S 2006 Crosstalk between extrinsic and intrinsic cell death pathways in pancreatic cancer: synergistic action of estrogen metabolite and ligands of death receptor family. Cancer Research 66 4309-4318.

Bu S, Blaukat A, Fu X, Heldin NE \& Landstrom M 2002 Mechanisms for 2-methoxyestradiol-induced apoptosis of prostate cancer cells. FEBS Letters 531 141-151.

Cailleau R, Olive M \& Cruciger QV 1978 Long-term human breast carcinoma cell lines of metastatic origin: preliminary characterization. In Vitro 14 911-915.

Carter J \& Pather S 2006 An overview of uterine cancer and its management. Expert Review of Anticancer Therapy 6 33-42.

Chauhan D, Catley L, Hideshima T, Li G, Leblanc R, Gupta D, Sattler M, Richardson P, Schlossman RL, Podar K et al. 2002 2-Methoxyestradiol overcomes drug resistance in multiple myeloma cells. Blood 100 2187-2194.

Chomczynski P \& Sacchi N 1987 Single-step method of RNA isolation by acid guanidinium thiocyanatephenol-chloroform extraction. Analytical Biochemistry 162 156-159.

Cuello M, Ettenberg SA, Nau MM \& Lipkowitz S 2001 Synergistic induction of apoptosis by the combination of trail and chemotherapy in chemoresistant ovarian cancer cells. Gynecologic Oncology 81 380-390.

Day JM, Tutill HJ, Newman SP, Purohit A, Lawrence HR, Vicker N, Potter BV \& Reed MJ 2006 17Beta-hydroxysteroid dehydrogenase type 1 and type 2 : association between mRNA expression and activity in cell lines. Molecular and Cellular Endocrinology 248 246-249.

Eagle H 1955 Propagation in a fluid medium of a human epidermoid carcinoma, strain KB. Proceedings of the Society for Experimental Biology and Medicine 89 362-364.

Engel LW, Young NA, Tralka TS, Lippman ME, O'Brien SJ \& Joyce MJ 1978 Establishment and characterization of three new continuous cell lines derived from human breast carcinomas. Cancer Research 38 3352-3364.

Franks S, MacLusky NJ \& Naftolin F 1982 Comparative pharmacology of oestrogens and catechol oestrogens: actions on the immature rat uterus in vivo and in vitro. Journal of Endocrinology 94 91-98. 
Gibson EM, Henson ES, Haney N, Villanueva J \& Gibson SB 2002 Epidermal growth factor protects epithelial-derived cells from tumor necrosis factor-related apoptosis-inducing ligand-induced apoptosis by inhibiting cytochrome $\mathrm{c}$ release. Cancer Research 62 488-496.

Gui Y \& Zheng XL 2006 2-Methoxyestradiol induces cell cycle arrest and mitotic cell apoptosis in human vascular smooth muscle cells. Hypertension 47 271-280.

Gunnarsson C, Olsson BM \& Stal O 2001 Abnormal expression of 17beta-hydroxysteroid dehydrogenases in breast cancer predicts late recurrence. Cancer Research 61 8448-8451.

Huang P, Feng L, Oldham EA, Keating MJ \& Plunkett W 2000 Superoxide dismutase as a target for the selective killing of cancer cells. Nature 407 390-395.

Joubert A, Maritz C \& Joubert F 2005 Bax/Bcl-2 expression levels of 2-methoxyestradiol-exposed esophageal cancer cells. Biomedical Research 26 131-134.

Keane MM, Ettenberg SA, Lowrey GA, Russell EK \& Lipkowitz S 1996 Fas expression and function in normal and malignant breast cell lines. Cancer Research 56 4791-4798.

Kopin IJ 1994 Monoamine oxidase and catecholamine metabolism. Journal of Neural Transmission. Supplementum 41 57-67.

Kuramoto H 1972 Studies of the growth and cytogenetic properties of human endometrial adenocarcinoma in culture and its development into an established line. Acta Obstetrica et Gynaecologica Japonica 19 47-58.

Lakhani NJ, Sarkar MA, Venitz J \& Figg WD 2003 2Methoxyestradiol, a promising anticancer agent. Pharmacotherapy 23 165-172.

LaVallee TM, Zhan XH, Herbstritt CJ, Kough EC, Green SJ \& Pribluda VS 2002 2-Methoxyestradiol inhibits proliferation and induces apoptosis independently of estrogen receptors alpha and beta. Cancer Research 62 3691-3697.

LaVallee TM, Zhan XH, Johnson MS, Herbstritt CJ, Swartz G, Williams MS, Hembrough WA, Green SJ \& Pribluda VS 2003 2-Methoxyestradiol up-regulates death receptor 5 and induces apoptosis through activation of the extrinsic pathway. Cancer Research 63 468-475.

Li L, Yu F, Wu X, Cheng J, Ulmsten U \& Fu X 2007 Effects of 2-methoxyestradiol on endometrial carcinoma xenografts. Journal of Cancer Research and Clinical Oncology 133 315-320.

Liu ZJ, Lee WJ \& Zhu BT 2005 Selective insensitivity of ZR75-1 human breast cancer cells to 2-methoxyestradiol: evidence for type II 17beta-hydroxysteroid dehydrogenase as the underlying cause. Cancer Research 65 5802-5811.

Maeda K, Tsuda H, Hashiguchi Y, Yamamoto K, Inoue T, Ishiko O \& Ogita S 2002 Relationship between p53 pathway and estrogen receptor status in endometrioidtype endometrial cancer. Human Pathology 33 386-391.

Merriam GR, MacLusky NJ, Picard MK \& Naftolin F 1980 Comparative properties of the catechol estrogens, I: methylation by catechol- $O$-methyltransferase and binding to cytosol estrogen receptors. Steroids 36 1-11.
Mooberry SL 2003 New insights into 2-methoxyestradiol, a promising antiangiogenic and antitumor agent. Current Opinion in Oncology 15 425-430.

Nishida M, Kasahara K, Kaneko M, Iwasaki H \& Hayashi K 1985 Establishment of a new human endometrial adenocarcinoma cell line, Ishikawa cells, containing estrogen and progesterone receptors. Nippon Sanka Fujinka Gakkai Zasshi 37 1103-1111.

Qadan LR, Perez-Stable CM, Anderson C, D'Ippolito G, Herron A, Howard GA \& Roos BA 2001 2-Methoxyestradiol induces G2/M arrest and apoptosis in prostate cancer. Biochemical and Biophysical Research Communications 285 1259-1266.

Ray G, Dhar G, van Veldhuizen PJ, Banerjee S, Saxena NK, Sengupta K \& Banerjee SK 2006 Modulation of cell-cycle regulatory signaling network by 2-methoxyestradiol in prostate cancer cells is mediated through multiple signal transduction pathways. Biochemistry 45 3703-3713.

Sadarangani A, Kato S, Espinoza N, Lange S, Llados C, Espinosa M, Villalon M, Lipkowitz S, Cuello M \& Owen GI 2007 TRAIL mediates apoptosis in cancerous but not normal primary cultured cells of the human reproductive tract. Apoptosis 12 73-85.

Sidor C, D'Amato R \& Miller KD 2005 The potential and suitability of 2-methoxyestradiol in cancer therapy. Clinical Cancer Research 11 6094-6095 (author reply 6095-6096).

Suchar LA, Chang RL, Rosen RT, Lech J \& Conney AH 1995 High-performance liquid chromatography separation of hydroxylated estradiol metabolites: formation of estradiol metabolites by liver microsomes from male and female rats. Journal of Pharmacology and Experimental Therapeutics 272 197-206.

Thews O, Lambert C, Kelleher DK, Biesalski HK, Vaupel P \& Frank J 2005 Possible protective effects of alpha-tocopherol on enhanced induction of reactive oxygen species by 2-methoxyestradiol in tumors. Advances in Experimental Medicine and Biology 566 349-355.

Utsumi T, Leese MP, Chander SK, Gaukroger K, Purohit A, Newman SP, Potter BV \& Reed MJ 2005 The effects of 2-methoxyoestrogen sulphamates on the in vitro and in vivo proliferation of breast cancer cells. Journal of Steroid Biochemistry and Molecular Biology 94 219-227.

Watanabe K, Takanashi K, Imaoka S, Funae Y, Kawano S, Inoue K, Kamataki T, Takagi H \& Yoshizawa I 1991 Comparison of cytochrome $\mathrm{P}-450$ species which catalyze the hydroxylations of the aromatic ring of estradiol and estradiol 17-sulfate. Journal of Steroid Biochemistry and Molecular Biology 38 737-743.

Williams AE, Maskarinec G, Franke AA \& Stanczyk FZ 2002 The temporal reliability of serum estrogens, progesterone, gonadotropins, SHBG and urinary estrogen and progesterone metabolites in premenopausal women. BMC Women's Health 213.

Yue W, Santen RJ, Wang JP, Li Y, Verderame MF, Bocchinfuso WP, Korach KS, Devanesan P, Todorovic R, Rogan EG et al. 2003 Genotoxic 
metabolites of estradiol in breast: potential mechanism of estradiol induced carcinogenesis. Journal of Steroid Biochemistry and Molecular Biology 86 $477-486$.

Zhou NN, Zhu XF, Zhou JM, Li MZ, Zhang XS, Huang P \& Jiang WQ 2004 2-Methoxyestradiol induces cell cycle arrest and apoptosis of nasopharyngeal carcinoma cells. Acta Pharmacologica Sinica 25 1515-1520.

Zhu BT \& Conney AH 1998 Functional role of estrogen metabolism in target cells: review and perspectives. Carcinogenesis 19 1-27. 